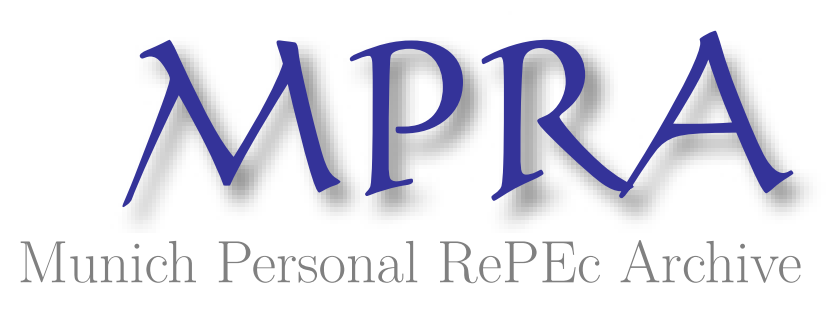

\title{
The Effects of Foreign Direct Investment in Mexico since NAFTA
}

\author{
Waldkirch, Andreas \\ Colby College
}

28 March 2008

Online at https://mpra.ub.uni-muenchen.de/7975/

MPRA Paper No. 7975, posted 29 Mar 2008 06:58 UTC 


\title{
The Effects of Foreign Direct Investment in Mexico since NAFTA*
}

\author{
Andreas Waldkirch ${ }^{\dagger}$
}

March 2008

\begin{abstract}
Foreign Direct Investment (FDI) into Mexico has increased dramatically since the inception of the North American Free Trade Agreement (NAFTA), raising questions about its effect on the Mexican economy. This paper studies the impact of FDI on industry productivity and wages over the first ten years of NAFTA, paying particular attention to the source country and destination industry of investments. It also offers a detailed description of the evolution of FDI, its components, sectoral composition, and sources from 1994-2005. There is evidence of a positive effect of FDI on productivity, particularly total factor productivity (TFP). The effect on wages is negative or zero at best, suggesting a divergence from productivity over this time period. The positive productivity effect stems largely from U.S. FDI into non-maquiladora industries, which receive over two thirds of manufacturing FDI. There is no evidence that more distant source countries have a differential effect. Consistent with theoretical expectations, FDI into maquiladoras benefits unskilled workers at the expense of skilled workers. This effect may be strong enough to dampen income inequality.
\end{abstract}

Keywords: Foreign Direct Investment, Mexico, NAFTA, Productivity, Wages, Income Inequality. JEL Classification: F15, F21, F23, O15.

\footnotetext{
${ }^{*}$ I thank seminar participants at the 4th Minnesota International Economic Development Conference, the Western Economic Association Conference in Seattle, the European Trade Study Group Conference in Athens/Greece and the North American Economics and Finance Association Winter Meetings in New Orleans and especially Sven Arndt and Galina Hale for useful comments on an earlier version of the paper.

${ }^{\dagger}$ Department of Economics, Colby College, 5244 Mayflower Hill, Waterville, ME 04901, USA.

E-mail: andreas.waldkirch@colby.edu. Phone: 207-859-5244. Fax: 207-859-5917.
} 


\section{Introduction}

In recent years, foreign direct investment (FDI) flows have increased more than either world trade or world production. For many developing countries, FDI has become an important, if not the most important source of external financing (UNCTAD, 2006). Driving at least some of this increase has been a widespread change in policies as countries have turned away from inward looking import substitution to embracing trade and foreign investment. FDI in particular is considered beneficial not only because it brings in much needed capital, but generates employment and presumably contributes to enhanced economic growth as it provides access to advanced technologies and spillovers, technological or otherwise (Borensztein et al., 1998; De Mello, 1999).

Despite the increased relative importance of FDI, only a few countries have been recipients of substantial absolute flows, among them China, Brazil, and Mexico. The latter has actively been trying to attract FDI since the 1980s, first by relaxing restrictions on foreign investment. ${ }^{1}$ However, these unilateral policies were not seen as sufficient as they were lacking a commitment effect. Thus, soon thereafter, Mexico pursued the North American Free Trade Agreement (NAFTA) whose expressly stated objective was to attract more FDI (Tornell and Esquivel, 1997). There is compelling evidence that the agreement has assured investors of Mexico's lasting commitment to reform and resulted in substantially and permanently higher FDI inflows, as documented, for example, in Waldkirch (2003) and Cuevas et al. (2005). Moreover, NAFTA has facilitated the evolution of a vertically integrated production network in North America, further changing the composition of FDI from predominantly market seeking to exploiting Mexico's comparative advantage. The rise in and changing nature of FDI raise questions about its effect on important economic outcomes such as productivity and income.

This paper examines the effect of FDI flows on total factor productivity (TFP), labor productivity, and wages in the post-NAFTA period. It pays particular attention to potential differential effects stemming from the source of the investment, its type and destination industry, which is rarely done in the literature. As, for example, Griffiths and Sapsford (2004) have pointed out, FDI from countries that are closer to the world technology frontier should have a greater positive impact than FDI from technologically less advanced countries, provided the host country's absorptive capacity is sufficiently high. Physical distance to investors' home countries may also matter.

\footnotetext{
${ }^{1}$ There was a major overhaul of Mexico's investment laws in 1989. Many obstacles to foreign investors, such as licensing requirements and restrictions pertaining to majority ownership, were removed. This change reversed Mexico's long-standing policy of reserving ownership in many sectors to Mexican nationals or the Mexican state and encouraging foreign investment only in sectors that were deemed crucial to the pursuit of import substitution policies.
} 
Firms from countries that are close by will have lower costs sourcing from their home countries than firms from more distant ones, who are more likely to source locally, thereby increasing the likelihood of spillovers (Javorcik et al., 2004; Rodríguez-Clare, 1996). FDI flowing into (unskilled) labor intensive industries may provide less technology and thus have little or no positive effect on industry productivity. In particular, FDI in the maquiladora industry is a candidate for investment that may not meet expectations with respect to productivity or wages, although by raising the relative demand for unskilled workers, it may help reduce income inequality. ${ }^{2}$ Given the detailed nature of the available FDI data, we can examine all of these hypotheses.

I emphasize that I make no attempt to assess the effect of NAFTA on Mexico. Given numerous other factors affecting the Mexican economy since 1994, such as the peso crisis, the East Asian crisis, the U.S. recession and political unrest to name but a few, it is hard, if not impossible, to disentangle the effects of the agreement. The goal of the paper is more modest in assessing the effect that FDI over this time period has had, although given that the case for NAFTA raising FDI inflows has been well established (see the earlier citations), there is certainly a presumption that the effects we find can at least in part be traced back to the agreement.

Mexico is not only an interesting case study due to its proximity to the United States and the controversy surrounding the effects NAFTA has had on it. It is also relevant for other (advanced) developing countries seeking or having recently concluded trade agreements with developed countries, such as Eastern European countries that have recently joined the European Union, Turkey, or Latin American countries in negotiations over trade agreements with the United States or Asian countries seeking closer economic integration with Japan.

Thus far, there is very little evidence on the effect of the sharply increased foreign participation in the Mexican economy in the wake of NAFTA. Ramirez (2006) examines the effect of FDI on labor productivity in Mexico from 1960-2001, thus mixing pre- and post-NAFTA years. Moreover, his analysis is at the country level and thus unable to discern differential effects at the industry level. López-Córdova (2003) uses firm-level data from annual surveys to examine FDI spillovers between 1993 and 2000. While his analysis is informative, the use of a non-representative sample does not provide a full account of the impact on the Mexican economy. The present study, in contrast, uses Industrial Census data, albeit at the industry level, which covers all firms. It also covers more

\footnotetext{
${ }^{2}$ Maquiladoras are in-bond assembly plants, largely located across Mexico's border with the United States. The maquiladora program has provided for reduced duties for Mexican exports into the U.S. since the 1960s. Upon re-importation, Section 9802 of the U.S. Harmonized Tariff Schedule stipulates that only the value-added part of the imported good is subject to duties.
} 
post-NAFTA years than any prior study that I am aware of, including the early 2000s when some commentators pointed out increasing problems in the Mexican economy (see, e.g., Cuevas et al., 2005).

The FDI data used is very detailed. I have annual data for 4-digit (Mexican Classification System, known by its Spanish acronym CMAP) manufacturing and non-manufacturing sectors, for a total of 128, distinguished by country of origin of the flow, for the years 1994-2005. Moreover, the data separate maquiladora FDI from other manufacturing FDI. While the regression analysis is confined to the manufacturing sector, a secondary contribution of this paper is to document the details of FDI into Mexico since NAFTA for all sectors. This descriptive evidence confirms some commonly held perceptions, such as the United States being by far the most important source of FDI, while dispelling others. For example, about half of FDI is into the services sector, mining receives a negligible amount of foreign investment, and only about 30 percent of manufacturing FDI is in maquiladoras.

The results are mixed from a welfare perspective. On the one hand, productivity, particularly total factor productivity, appears to be positively affected by FDI, specifically U.S. FDI into nonmaquiladora industries. On the other hand, the effect on average compensation per worker is negative or zero at best, depending on the specification, even after controlling for many other determinants of compensation such as capital intensity, scale economies, the composition of the work force and unobserved heterogeneity at the industry level. Together, these findings suggest that the owners of capital benefit from productivity improvements rather than labor. There is also some evidence that maquiladora FDI may indeed help dampen income inequality by raising the relative demand for and thus the wages of unskilled workers.

The paper proceeds as follows. The next section provides a detailed description of the evolution of FDI in Mexico from 1994-2005, followed by a more extensive literature review. I then discuss some pertinent theoretical considerations before laying out the empirical methodology, which is based on a simple theoretical model and includes a thorough discussion of TFP measurement. After providing some evidence on the changing nature of FDI in the wake of NAFTA, the regression results are analyzed. The final section concludes. 


\section{FDI in Mexico Since NAFTA}

This section provides a detailed description of the magnitude, sources and destination industries of FDI in Mexico in the post-NAFTA period. Between 1994 and 2005, FDI flows into Mexico total about $\$ 170$ billion, as shown in Table 1 and Figure $1 .^{3}$ The bulk of foreign investment goes into the manufacturing and services sectors, about the same amount over this time period. About 30 percent of manufacturing FDI is in maquiladoras, a share that is fairly constant. This is remarkable for two reasons. First, the main advantage of maquiladoras, that tariffs apply only to the value added in Mexico, should be eroding as tariffs fall to zero due to NAFTA. Thus, one would expect a declining share of maquiladora investment. Second, the large share of non-maquiladora investment shows that manufacturing operations by foreign multinationals in Mexico do not just consist of the assembly of final goods destined for export to the United States or elsewhere. ${ }^{4}$ Within services, over 20 percent are in wholesale and retail trade, where flows do not fluctuate much. Most of the fluctuation in the services sector is due to large acquisitions in banking. Finally, agriculture and mining receive negligible amounts of foreign investment.

The United States has historically been and remains the most important source of FDI, as can be seen in Table 2. Over the whole sample period, over 60 percent of FDI originates there. Other important source countries are predominantly developed, as evidenced by the OECD share of over 95 percent. The European Union, chiefly the United Kingdom, Germany, Spain and France, account for about 25 percent of all flows. Developing countries are negligible as sources of FDI. ${ }^{5}$

Table 3 breaks the manufacturing sector down into eight subsectors and provides more detail on services subsectors as well. Nearly half of manufacturing FDI has gone into metals, electrical machinery and automobiles, with the latter accounting for a little over one third of that. Significant investments have also been made in food processing and the chemical industry. Over 40 percent of services FDI is in banking and insurance, reflecting several large scale investments in Mexican banks, most following troubles in the late 1990s which led to a relaxation of foreign ownership rules in that sector, now allowing for majority foreign ownership. The table also shows the share of selected source countries for these subsectors. While the United States accounts for the largest share of FDI in many sectors, other countries are important in some. This includes Canada, the other NAFTA partner, in publishing and clay, glass and cement; the UK in food and tobacco;

\footnotetext{
${ }^{3}$ The data are from the Secretaría de Economía, which reports them in U.S. dollars.

${ }^{4}$ While maquiladoras are no longer required to export all of their output, in practice, most still do.

${ }^{5}$ In fact, most of that flow consists of the acquisition of the steel company Siderurgica del Balsas by Mittal Steel from India in 1994.
} 
Spain in communications, banking and insurance and other non-traded services sectors; and Japan in automobiles.

\section{Related Literature}

There is a considerable literature studying productivity effects from foreign investment in Mexico, although there is a paucity of recent, post-NAFTA work. Two early studies that find positive spillover effects of multinationals in a cross-section of industries in Mexico are Blomström (1986) and Blomström and Wolff (1994), both of which use data from 1970 and 1975. Jordaan (2005), using data from the 1994 Industrial Census, finds that positive externalities from the presence of foreign firms hinge on the size of technological differences between them and domestic firms. However, as Görg and Greenaway (2004) and others have emphasized, finding evidence of productivity effects in a cross-section is not convincing due to a clear endogeneity problem. It is likely that foreign firms are attracted to more productive industries or will acquire more productive firms in the first place and thus the observed correlation between the degree of foreign ownership and productivity is a spurious one. Only with more years of data can this self-selection effect be controlled for.

More recently, Ramirez (2006) examines the effect of FDI on labor productivity growth in Mexico over the period 1960-2001, using economy-wide aggregate data. While the focus is not on the post-NAFTA period, some years are included. He finds a positive effect of foreign investment per worker, which, however, is diminishing over the time period studied. There are two recent studies that use Mexican plant-level data. López-Córdova (2003) is closest to this paper in that he explores NAFTA and manufacturing productivity, finding positive inter-, but negative intra-industry

spillovers. He, as well as Alfaro and Rodríguez-Clare (2004), who explore inter-industry linkages more thoroughly, use data that come from the annual industrial survey, which oversamples large plants and is not a representative sample. Moreover, the data extend only until 2000. Another study that uses the annual survey in documenting the evolution of total factor and labor productivity in Mexico from 1994-2002 is Montes-Rojas and Santamaria (2007). While they find a positive effect of international trade, they do not examine the effect of FDI.

In a seminal study of Venezuela, Aitken and Harrison (1999) find that positive productivity effects are confined to plants with foreign equity participation, and then only small ones, but that domestic plants are negatively affected, with a very small overall positive effect. In a large panel study of over 30 OECD and non-OECD countries De Mello (1999) finds that FDI has a positive 
effect on TFP growth in OECD countries, but no or even a negative effect in non-OECD ones. He also finds that the effect of FDI on capital accumulation is nonexistent or negative in the former, but positive in the latter. Put together, these findings lead him to conclude that in technologically laggard countries, there exists a complementarity effect between FDI and domestic investment, resulting in a reduction in TFP growth as FDI enters. For technological leaders, on the other hand, there is a substitution effect, perhaps because older capital is made obsolete more quickly and comprehensively by the introduction of new capital via FDI.

In their extensive survey of the literature, Görg and Greenaway (2004) find that the evidence on productivity and spillovers is mixed and depends largely on the study methodology and data used. While they point out that ideally, a panel of firms observed over a number of years should be used to elicit productivity effects of foreign investment, they emphasize that it is particularly crucial to have more than a cross-section in order to be able to deal with self-selection bias and unobserved heterogeneity. In addition, Görg and Strobl's (2001) meta-analysis points out that there appears to be some publication bias, which suggests that the evidence is even more mixed than a review of published studies suggests.

As far as wages are concerned, Aitken et al. (1996), in a study of Venezuela, Mexico and the United States, find that foreign presence has a positive overall effect on wages in Mexico, both skilled and unskilled, with a larger effect on the former, suggesting that FDI might be inequalityenhancing. Similarly, Feenstra and Hanson (1997) document the inequality increasing effect of foreign investment. Their explanation is that operations that are outsourced from the United States tend to be unskilled labor-intensive from the outsourcing country's point of view, but tend to be skilled labor-intensive from the recipient country's point of view, due to differences in the range of goods produced. While the finding that multinationals pay higher wages in developing countries is fairly robust (see the summary of evidence in Lim (2001), pp. 39-41), Lipsey (2002), in his comprehensive review of FDI effects, concludes that the evidence on overall wage effects is relatively scarce. If anything, existing studies seem to find a slightly positive effect that is stronger for white collar than for blue collar workers.

There are several studies of income inequality in Mexico that look at the effect of trade liberalization without explicit consideration of the coincident rise in FDI. Examples include Hanson and Harrison (1999), Feliciano (2001) and Esquivel and Rodríguez-López (2003). Hanson and Harrison (1999) study the period 1984-90 and find that the rise in wage inequality could be due to low-skill intensive sectors disproportionately being affected by trade liberalization and consequently more 
competition from economies with large reserves of unskilled labor. Feliciano (2001) finds that trade liberalization has contributed to rising wage inequality in Mexico, but finds no effect on employment. Esquivel and Rodríguez-López (2003) include a comparison of the period before NAFTA (1988-1994) and the first six years of NAFTA (1994-2000) and find that trade liberalization would have led to a reduction in the wage gap; however, its effect was offset by a large negative impact of technological progress on the real wage of unskilled workers for the first six year period. During the first six years of NAFTA, the effect of trade liberalization is found to be zero. Hanson (2003, 2007), using data from the 1990 and 2000 Population Censuses, finds little evidence of wage convergence between the United States and Mexico, but a continued rise in returns to skill throughout the 1990s, some of which he attributes to "globalization", including FDI. Finally, Taylor and Driffield (2005) look at the effect of FDI on wage inequality in the UK and find that after controlling for technology and trade, FDI explains on average 11 percent of wage inequality.

\section{Theoretical Considerations}

The entry of foreign firms into a market affects productivity and wages for several reasons. Since foreign owners are inherently disadvantaged relative to domestically owned firms with superior knowledge of local markets and practices, they must possess firm-specific advantages in the form of proprietary assets, technology or management and marketing practices (what Markusen (2002) terms 'knowledge capital'). These imply higher productivity of foreign-owned firms themselves. Moreover, there may be benefits to local firms stemming from productivity spillovers. Productivity spillovers generally take place when the entry or presence of multinational firms leads to efficiency or productivity benefits for local firms that are not fully internalized by the foreign firm (Blomström and Kokko, 1998). For example, host country workers that they hire and train may leave and join or set up local firms. Marketing practices may be observed and imitated. Multinationals have an interest in containing spillovers since these tend to reduce their advantage and thus their profits, but are not entirely able to do so.

The entry of multinational firms into a market may also affect productivity by disturbing the existing market equilibrium. Entry may erode the market power of existing indigenous firms, reducing measured productivity, which reflects market power as well as technical efficiency (Bernard

et al., 2003). Thus, the effect of foreign entry on domestic firms' productivity is ambiguous. The overall impact on an industry is determined by the combination of foreign superiority, spillovers 
and competition effects.

A number of FDI characteristics are indicators of the possible scope of foreign productivity advantages and spillovers, but this discussion focuses on those that can be addressed in the empirical work. They include the source country of investment and the destination industry. Labor-intensive, low-technology industries such as the maquiladoras may receive investment in order to exploit labor cost advantages, but rely on well-known technologies and require little skill, limiting the scope of spillovers. Put differently, vertical FDI is less likely to generate positive productivity effects than horizontal investment. ${ }^{6}$

Investment from countries close to or at the world technology frontier, such as the United States, is more likely to provide previously unavailable assets than investment from countries at a similar distance to the frontier (Griffiths and Sapsford, 2004). But even among advanced countries, there are likely to be differences. Firms from countries that are close by will have lower costs sourcing from their home countries than firms from more distant ones, who are more likely to source locally (Javorcik et al., 2004; Rodríguez-Clare, 1996). Home country sourcing is also higher for firms from countries with whom the host has concluded preferential trade agreements. In the case of Mexico, the U.S. is both close by and a partner in a trade agreement. ${ }^{7}$ Both distance and the existence of preferential trade in turn affect the likelihood of FDI being of the vertical or of the horizontal kind. Firms from close-by countries where re-exports face low tariffs are more likely to exploit factor price differences, thus engaging in vertical FDI, whereas firms from more distant countries are likely to be market seeking and thus engage in horizontal FDI. However, the opportunity for firms outside of a free trade agreement to engage in export platform investment, provided rules of origin are satisfied, may muddle this distinction. ${ }^{8}$ In summary, U.S. FDI is expected to have a greater productivity effect than non-U.S. FDI due to its technological superiority, but a lesser effect due to NAFTA and its proximity. Hence, this must be determined empirically.

To the extent that wages reflect productivity, the effect of FDI on them should be similar to its effect on productivity. However, skilled and unskilled workers may be affected differently, for several reasons. Increasing capital flows, as in the wake of NAFTA, should raise the demand for skill and thus contribute to rising wage inequality since capital and skill tend to be complementary.

\footnotetext{
${ }^{6}$ Although recall Feenstra and Hanson's (1997) argument that the outsourced activities may appear skilled-labor intensive from the recipient country's point of view.

${ }^{7}$ Subsequent to NAFTA, Mexico has also concluded bilateral free trade agreements with a number of other countries, most notably the European Union in 1999.

${ }^{8}$ There are additional reasons why distinguishing source countries is important. For example, Levy Yeyati et al. (2007) find that U.S. and European outward FDI behave differently from Japanese outward FDI because the former move countercyclically while the latter moves procyclically.
} 
This may not be the case for maquiladora investment, however, if it raises the relative demand for unskilled workers. More generally, trade liberalization should result in the convergence of goods and factor prices. This should raise both unskilled and skilled wages, where the Stolper-Samuelson Theorem predicts that for an unskilled-labor abundant country such as Mexico, the skill premium should fall as unskilled wages rise relatively more. ${ }^{9}$ Thus, this again becomes an empirical question.

\section{$5 \quad$ Empirical Methodology}

Consider a standard Cobb-Douglas production function

$$
Y_{i t}=A_{i t} K_{i t}^{\alpha_{1}} L_{i t}^{\alpha_{2}} e_{i t}
$$

where $Y_{i t}$ is value added, $A_{i t}, K_{i t}$ and $L_{i t}$ denote total factor productivity (TFP), capital and labor in sector $i$ at time $t$, respectively, and $e$ is a random disturbance term. Note that I do not impose constant returns to scale. Taking natural logarithms and re-arranging slightly, we obtain

$$
y_{i t}=\alpha_{1} k_{i t}+\alpha_{2} l_{i t}+\omega_{i t}+\varepsilon_{i t}
$$

where lower case letters denote $\log$ values, $\omega_{i t}=\ln \left(A_{i t}\right)$ and $\varepsilon_{i t}=\ln \left(e_{i t}\right)$. TFP is taken to be influenced by the foreign presence in the sector and other factors to be made precise below. But first I need to discuss how to estimate $\omega_{i t}$ in equation (2). The basic problem in estimating (unobserved) sector- and time-specific productivity is that decision makers may observe it, which conditions their input choices, but the econometrician does not. If this is the case, there is a simultaneity problem, which means that the variable inputs and $\omega_{i t}$ are correlated and thus ordinary least squares (OLS) would produce inconsistent estimates. There are several solutions which have been proposed. Olley and Pakes (1996) proxy for $\omega_{i t}$ by introducing an investment function

$$
i n v_{i t}=f_{t}\left(\omega_{i t}, k_{i t}\right)
$$

which, if $i n v_{i t}$ is monotonically increasing in $\omega_{i t}$, can be inverted and then substituted into the production function (2). The problem is that this procedure requires strictly positive investment and observations that show zero investment must be dropped. Levinsohn and Petrin (2003) rely on

\footnotetext{
${ }^{9}$ Various explanations have been put forward for factor price changes that are at odds with neoclassical theory, such as that by Feenstra and Hanson (1997) discussed above. Bernard et al. (2004) contend that an extremely uneven regional factor distribution in Mexico ("lumpiness") can also prompt production and trade patterns that are contrary to overall comparative advantage.
} 
intermediate input usage instead, which is available in the Mexican data. Consider the intermediate input demand function

$$
m_{i t}=g_{t}\left(\omega_{i t}, k_{i t}\right)
$$

which, if $m_{i t}$ is monotonically increasing in $\omega_{i t}$, can be inverted to obtain

$$
\omega_{i t}=g_{t}^{-1}\left(m_{i t}, k_{i t}\right)
$$

The only additional assumption needed to proceed with the estimation of productivity is that it follows a first-order Markov process. Substituting (5) into (2) gives

$$
y_{i t}=\alpha_{1} k_{i t}+\alpha_{2} l_{i t}+g_{t}^{-1}\left(m_{i t}, k_{i t}\right)+\varepsilon_{i t}
$$

which can be written as

$$
y_{i t}=\alpha_{2} l_{i t}+\phi_{t}\left(m_{i t}, k_{i t}\right)+\varepsilon_{i t}
$$

where $\phi_{t}\left(m_{i t}, k_{i t}\right)=\alpha_{1} k_{i t}+g_{t}^{-1}\left(m_{i t}, k_{i t}\right)$. The function $\phi_{t}$ can be estimated with a third-order polynomial approximation in $m_{i t}$ and $k_{i t}$, and thus this first stage of the estimation yields the estimate $\widehat{\alpha}_{2}$ of $\alpha_{2}$.

Since it cannot be identified separately when estimating equation (7), the coefficient on capital, $\alpha_{1}$, is obtained in a second estimation stage, which I will sketch briefly. From (7), one computes an estimated value $\widehat{\phi}_{t}$, which can be used to compute a prediction for $\omega_{i t}$ for any candidate value $\alpha_{1}^{*}$ using $\widehat{\omega}_{i t}=\widehat{\phi}_{t}-\alpha_{1}^{*} k_{i t}$. Using these values, a consistent approximation of the expected value of $\omega_{i t}$ is given by the predicted values of the regression

$$
\widehat{\omega}_{i t}=\gamma_{0}+\gamma_{1} \omega_{i t-1}+\gamma_{2} \omega_{i t-1}^{2}+\gamma_{3} \omega_{i t-1}^{3}+\epsilon_{i t} .
$$

Then, the estimate $\widehat{\alpha}_{1}$ of $\alpha_{1}$ is found as the solution to minimizing the sample residual of the production function with respect to $\alpha_{1}^{*}$. A bootstrapping procedure is used to construct the standard errors for $\widehat{\alpha}_{1}$ and $\widehat{\alpha}_{2}$. For further details, see Levinsohn and Petrin (2003). I implement this procedure using the 'levpet' command in STATA, which was written by Levinsohn, Petrin and Brian Poi (see also Petrin et al., 2004).

Now, TFP is modeled as a function of foreign presence and other factors that matter according to theory:

$$
t f p_{i t}=\beta_{0}+\beta_{1} F D I_{i t}+\beta_{2} Q L_{i t}+\beta_{3} \text { Scale }_{i t}+\beta_{4} \text { Conc }_{i t}+\psi_{i t}
$$

where $F D I$ is foreign direct investment, $Q L$ the quality of labor, Scale the scale of production, Conc a measure of industry concentration and $\psi_{i t}$ an iid error. For notational convenience and 
to distinguish what follows from the procedure of estimating TFP, $\omega_{i t}$ is replaced by $t f p_{i t}$. Data is available from three Industrial Census years, 1994, 1999, and $2004(t)$ for 52 manufacturing industries $(i)$ where the data in each case refer to the previous year. ${ }^{10}$ FDI is measured as annual flows. Thus, it is natural to aggregate accumulated flows between Census years as a measure of the change in the degree of foreign presence in a particular industry between Censuses. Consequently, outcome and control variables would also be measured as changes. However, since FDI flows as measured are not adjusted for capital depreciation, at least some of these flows will not change the level of foreign capital. Since there is no other measure of foreign capital, the analysis will use both levels and changes of all variables other than FDI. If foreign investment has a positive effect on TFP, $\beta_{1}$ will be greater than zero.

The first control variable to take into account is the quality of labor. A higher average labor quality or equivalently skill level is likely to result in higher productivity. This is proxied by the share of skilled workers in the total labor force of an industry, calculated using workers' remuneration shares rather than the number of workers. At this point, a brief discussion of the measures of "skilled" and "unskilled" workers is in order. The Mexican Industrial Census distinguishes obreros, who are equivalent to blue-collar or production workers, and empleados, who are equivalent to white-collar or non-production workers. Hanson and Harrison (1999) further note that blue-collar worker activities include machine operation, production supervision, repair, maintenance, and cleaning. Those of white-collar workers include management, product development, administration, and general office tasks. It is common in work on Mexico to identify white-collar workers as skilled labor and blue-collar workers as unskilled labor (Hanson and Harrison, 1999). While there are obvious shortcomings with this distinction, no other breakdown is available for Mexico. There is information on both the number of such workers as well as their respective compensation. ${ }^{11}$ Thus, in constructing the share of skilled workers either measure can be used, although the results are not affected by which one is chosen. ${ }^{12}$

Another important control is the scale of production. Industries that are characterized by economies of scale are likely to have higher total factor productivity, ceteris paribus. The Census

\footnotetext{
${ }^{10}$ Petroleum-related industries, where FDI is severely restricted, are dropped from the analysis, as is the tobacco sector, which is an obvious outlier.

${ }^{11}$ Information on the number of hours worked annually are only available in the 1999 and 2004 Census, not the 1994 one. Hanson and Harrison (1999) show, using annual survey data for 1984-1999, that the correlation between number of workers and hours worked is extremely high. This is the case for the 1999 and 2004 data as well.

${ }^{12}$ Leamer (1998) suggests a classification that is based on compensation. It assumes that the industry with the lowest average wage consists of unskilled workers only, whereas the industry with the highest average wage consists of skilled workers only. The other industries fall in between. Using this classification also makes very little difference to the results.
} 
provides a limited amount of information, so production scale is proxied by the average output per plant in a sector. A positive coefficient sign on this variable is expected.

Industries with a higher concentration of firms are expected to have higher productivity due to the higher markup firms are able to charge. Unfortunately, no concentration measure such as the Herfindahl Index is available for all three Census years. Thus, we use the number of plants per sector. Given that we have already controlled for average plant size, this should provide a reasonable proxy for (the inverse of) industry concentration. Thus, a negative coefficient sign on this variable is expected.

One well-known problem with using industry-level data is that differences in productivity across sectors might be correlated with foreign activity because foreign firms are attracted to sectors that already have higher productivity. If that is the case, then failing to control for differences across industries is likely to find a positive correlation between FDI and industry productivity. A common solution to this problem is the use of industry fixed effects, which is possible here. These will also account for unobserved heterogeneity across industries other than initial productivity.

Still, since the time dimension of this panel is very short, and thus the inclusion of fixed effects reduces the available degrees of freedom considerably, identification of FDI effects may be difficult. There is another way to control for a possible self-selection effect. The 1994 Census data pertain to 1993, the year just before the inception of NAFTA and the first year of the FDI data. Thus, one can include an "initial condition". That is, use productivity in 1998 and 2003 as the dependent variable, regressed on previously accumulated FDI and the control variables and include 1993 productivity. If foreign firms are disproportionately attracted to industries that were more productive to begin with, the 1993 productivity control will account for that. Since this initial condition is only available as a level control, it will not be employed when TFP and the other variables are measured as changes.

Thus, the three basic models to be estimated are

$$
\begin{gathered}
t f p_{i t}=\beta_{0}+\beta_{1} F D I_{i t}+\beta_{2} Q L_{i t}+\beta_{3} \text { Scale }_{i t}+\beta_{4} \text { Conc }_{i t}+t f p_{i, 1993}+\psi_{i t} \\
t f p_{i t}=\beta_{0}+\beta_{1} F D I_{i t}+\beta_{2} Q L_{i t}+\beta_{3} \text { Scale }_{i t}+\beta_{4} \text { Conc }_{i t}+\mu_{i}+\psi_{i t} \\
\Delta t f p_{i t}=\beta_{0}+\beta_{1} F D I_{i t}+\beta_{2} \Delta Q L_{i t}+\beta_{3} \Delta \text { Scale }_{i t}+\beta_{4} \Delta \text { Conc }_{i t}+\mu_{i}+\psi_{i t}
\end{gathered}
$$

where $\Delta$ denotes changes and $\mu_{i}$ is a fixed effect. All variables except dummies and share variables are expressed in logs.

As mentioned above, FDI is total cumulative FDI flows over the years preceding the Census year. I use the simple sum of FDI from all source countries in a base specification. In order to 
test the hypothesis that distance to the source matters for the effect of FDI, I also construct a distance-weighted measure of total FDI:

$$
F D I_{i t}^{d w}=\sum_{c}\left\{\left(F D I_{i t c} \cdot d_{i s t_{c}}\right) / \sum_{c} d i s t_{c}\right\}
$$

where dist is distance between the source country and Mexico ${ }^{13}$ and $c$ indexes countries. If firms from more distant countries are more likely to source locally and thus provide greater spillovers, the effect of distance-weighted FDI on productivity and wages should be greater than that of the simple sum of all FDI. On the other hand, the closest source country is also the most technologically advanced, the U.S., which is also the NAFTA partner country. These facts may easily confound the hypothesized effect of distance. In order to check for the possibility that the effect of U.S. FDI is fundamentally different from that of other sources, I split FDI into that originating in the U.S. and that originating elsewhere. More generally, finding differential effects would support the hypothesis that the source country of FDI matters.

The data also distinguish FDI flowing into maquiladoras versus all other FDI. Thus, in another specification, I enter maquiladora and non-maquila FDI separately since the two may have different effects. In particular, since maquiladoras are mainly low-technology assembly plants and are thus largely consistent with vertical FDI, one would expect no or less of an effect. More generally, finding differential effects would support the hypothesis that the industry destination of FDI matters. Checking the role of distance, source and destination of FDI is rarely done in the literature and thus constitutes an important contribution of this study.

While I hypothesize that foreign presence affects total factor productivity and thus a regression of TFP on FDI and controls is an appropriate approach, the model outlined above suggests a complementary, indirect approach. Instead of going through the procedure of estimating TFP, we can directly estimate the effect of foreign presence on labor productivity. This approach is also useful for comparing the results of this study to earlier ones that use only labor productivity, not TFP. Consider again the standard Cobb-Douglas production function (1). Dividing it by $L$ and taking natural logs yields

$$
l p_{i t}=t f p_{i t}+\beta_{5} k l_{i t}+\beta_{6} k_{i t}+\eta_{i t}
$$

\footnotetext{
${ }^{13}$ Distance in kilometers is a complex measure taken from Centre d'Etudes Prospectives et d'Informations Internationales (CEPII) which uses domestic and international distance weighted by the population concentration in important cities within a country. However, the measure is highly correlated with simpler distance measures and results are not affected by the choice of distance. Note that this measure provides the shortest distance for U.S.-Mexico, whose distance is not obvious, but important for this study.
} 
where $l p=\ln (Y / L)$ is $\log$ value added per worker (labor productivity), $k l=\ln (K / L), k=\ln (K)$, $\beta_{5}=\left(1-\alpha_{2}\right), \beta_{6}=\left(\alpha_{1}+\alpha_{2}-1\right)$ and $\eta_{i t}$ is an error term. Substituting (9) into (14) yields

$$
l p_{i t}=\beta_{0}+\beta_{1} F D I_{i t}+\beta_{2} Q L_{i t}+\beta_{3} \text { Scale }_{i t}+\beta_{4} \text { Conc }_{i t}+\beta_{5} k l_{i t}+\beta_{6} k_{i t}+\chi_{i t}
$$

where $\chi_{i t}=\eta_{i t}+\psi_{i t}$. That is, with labor productivity as the dependent variable we must add the capital-labor ratio as well as capital by itself. Note that equations (10) - (12) change accordingly.

Similarly, we can derive an expression for wages paid. Assuming that workers earn their marginal product, we obtain an expression for (log) wages per worker by taking the partial derivative of (1) with respect to $L$, divide by $L$, take natural logs and substitute for TFP to obtain

$$
w p w_{i t}=\delta_{0}+\delta_{1} F D I_{i t}+\delta_{2} Q L_{i t}+\delta_{3} \text { Scale }_{i t}+\delta_{4} \text { Conc }_{i t}+\delta_{5} k l_{i t}+\delta_{6} k_{i t}+\tau_{i t}
$$

where $w p w$ is (the natural $\log$ of) wages per worker, $\delta_{5}=\left(2-\alpha_{2}\right), \delta_{6}=\left(\alpha_{1}+\alpha_{2}-2\right)$ and $\tau_{i t}$ is again an iid error term. As discussed earlier, existing literature finds ambiguous effects of the presence of foreign firms in an industry on overall wages. Often, foreign firms pay higher wages, but there is a negative spillover effect on domestic firms, where the total effect could then go either way. This total effect, however, is what matters both for policy makers as well as for workers on average. Even if foreign firms pay higher wages, if they crowd out domestic firms sufficiently, or simply poach the best workers from them, the notion that FDI is beneficial is at least questionable. Since data on skilled and unskilled worker compensation is available separately, I can also investigate the effect of FDI on these types of wages as well as on income inequality, measured as the share of total compensation accruing to skilled workers. A detailed description of all data and sources is provided in the Data Appendix.

Before turning to the results, I emphasize that the Census data used here provide a comprehensive account of the manufacturing sector, unlike the annual industrial survey, which is used, for example, in López-Córdova (2003) and Alfaro and Rodríguez-Clare (2004) and does not constitute a representative sample. Moreover, since the focus is on long-term trends, 5-year intervals seem appropriate. Finally, the fact that a Census was conducted just prior to the inception of NAFTA and the coincident availability of detailed FDI data provides an ideal control for initial conditions. A downside of the data is that it is industry- rather than plant-level data. For confidentiality reasons, plant-level data from the Census is unavailable and thus this study must confine the analysis to the industry-level, as other studies using Census data, e.g. Jordaan (2005), have. 


\section{Results}

\subsection{A View From Trade}

Before proceeding to the regression analysis, this subsection presents some suggestive evidence on the nature of FDI in the wake of NAFTA, which has implications for its expected effect on productivity, as discussed above. Recall that FDI can roughly be classified as horizontal (market seeking) or vertical (exploiting comparative advantage). ${ }^{14}$ Robertson (2006), using U.S. and Mexican manufacturing employment data, documents that before NAFTA, Mexican and U.S. production workers are within-sector substitutes, whereas following NAFTA, they tend to be complements. This finding is indirect evidence that post-NAFTA FDI tends to be of the vertical kind.

I take a different approach and instead compute an index of intra-industry trade (IIT) by sector and correlate it with FDI. Exports and imports in an industry are both high when parts and components are imported for final assembly and then reexported, reflecting vertical integration. Thus, a positive correlation between an IIT index and FDI is consistent with vertical FDI. If, however, FDI flows into industries with little intra-industry trade, it is more likely a substitute for trade and thus of the horizontal kind. Simple correlations of course do not imply causation, but they provide at least some indication of the nature of FDI in Mexico.

The correlations shown in Table 4 distinguish between maquila, non-maquila and total FDI. The intra-industry trade index is a simple index also known as the Grubel-Lloyd $(1971,1975)$ index. Trade data come from Robert Feenstra's database at the Center for International Data at UC Davis and are constructed from United Nations trade data.

The top third of the table shows FDI-IIT correlations using the raw Grubel-Lloyd index (lagged by one year). When all available year-country-sector observations are used, there is a positive and significant correlation between FDI and intra-industry trade. Importantly, it is larger for maquila FDI, as expected. When, in columns 4-6, only U.S. data is used to construct the IIT index (but still all countries' FDI), the correlation becomes smaller and retains significance only for total and maquila FDI, despite the greatly increased number of observations.

Since annual values may be too volatile, I next look at changes in IIT since these could be indicative of the changing nature of a sector and thus more highly correlated with subsequent FDI. However, the results in rows 4-6 indicate that this is not the case as even the correlations that

\footnotetext{
${ }^{14}$ This classification is of course a simplification as no investment is likely to be purely horizontal or vertical and there are bound to be many cases of "complex" FDI (Yeaple 2003). Still, it is prevalent in the literature.
} 
are statistically significant are very small. The final three rows thus look at the value of IIT in 1993, just before the inception of NAFTA, and its correlation with subsequent cumulative FDI. The correlation for maquiladora FDI is now larger, in particular when each country's own data is used to compute the IIT index, supporting the notion that this FDI is of the vertical kind. Overall, these simple correlations point to some differences in FDI flowing into maquiladora versus nonmaquiladora industries and thus provide additional support for characterizing maquiladora FDI as vertical in the subsequent regression analysis.

\subsection{FDI Effects}

The results for the effect of FDI on various outcomes are shown in Tables 6 through 11. In order to have a comparable sample, all regressions are run using only those sectors for which there is complete information for all FDI components. All regressions report heteroscedasticity consistent standard errors and include a 2003 dummy (not reported). Table 5 contains summary statistics for all variables.

Tables $6 \mathrm{a}$ and $6 \mathrm{~b}$ contain the results for total factor productivity for the three models (10) - (12) described above. The first three columns of Table 6a use total FDI whereas the remaining three columns use the distance-weighted FDI measure. The estimated effect of FDI differs significantly between the two FDI measures for two of the three models. Unweighted FDI has no effect on TFP when 1993 TFP is included to correct for self-selection. It becomes significantly positive, however, for both models that include industry fixed effects. For TFP levels, the estimated elasticity suggests that a 10 percent higher FDI corresponds to a half percent higher TFP. The elasticity for the change in TFP is about three times as high. Conversely, distance-weighted FDI is never estimated to exert a significantly positive effect and thus all coefficients are no larger than those on unweighted FDI. No model thus supports the hypothesis of more distant FDI having a larger productivity effect.

The control variables perform reasonably well considering the sample size and model design. Labor quality is never significant, although it will be in later specifications and then always with the expected positive sign. Scale economies appear to be important only when no fixed effects are included and concentration has an unexpected positive sign (recall it is proxied by the number of plants, so a negative sign is expected). However, it is only marginally significant, and when industry fixed effects are included, none of the controls is significant. The initial level of TFP itself is highly significant and positive, as expected. The insignificance of other controls in the fixed effects specifications is not particularly surprising given the short time dimension and thus relatively little 
variation. Thus, it is all the more striking that FDI is estimated to exert a significantly positive effect on productivity. Note also that in each case the $\mathrm{R}^{2}$ is relatively high. In the first model, much of that is due to the initial condition, as TFP is quite persistent; and this is typical in fixed effects regressions. Ramsey's RESET test for omitted variables consistently indicates that no variables appear to be missing from the model, although it is well-known that the test has relatively low power.

The basic result is in contrast with the findings of López-Córdova (2003), who found no effect of FDI (levels or changes) on productivity in the same industry except in one levels regression when he did not control for plant ownership. He did find evidence of intra-industry spillovers, which we cannot examine here. We can, however, examine the effect of different sources and different destination industries of FDI.

In Table 6b, I split (unweighted) FDI by destination and by source country. The first three columns split FDI into maquiladora and non-maquiladora FDI. There is a stark contrast between the model with initial conditions and those that include fixed effects. The first model has a significantly positive coefficient on maquila FDI, although it is economically small. Conversely, the fixed effect models both have a significant coefficient on non-maquiladora FDI, suggesting it has a positive effect on TFP levels and growth, supporting the hypothesis that horizontal rather than vertical FDI promotes productivity. The magnitude is roughly comparable to that of total FDI. The differential effects lead one to suspect that controlling for baseline TFP may avoid the self-selection bias, but not the presence of unobserved heterogeneity, which requires the fixed effects. Thus, we have more confidence in the results of the latter models.

The last three columns split FDI into that which originates in the United States and that which originates in other countries. The coefficients on U.S. FDI all have the same signs and almost all have the same significance levels as total FDI. An exception is model (11) which is just outside of conventional significance levels. Conversely, the coefficient on non-U.S. FDI is not statistically significant. This illustrates how total FDI is dominated by U.S. FDI which appears to have a positive effect. It is interesting to note that this occurs even though most maquiladora FDI, which is not found to have a positive effect on TFP, originates in the U.S. However, a significant amount of non-maquiladora FDI does as well. More generally, the results illustrate how examining only total FDI obscures some of the underlying regularities, such as the importance of the source as well as the destination of FDI in the host country. The size and significance levels of the control variables, the $\mathrm{R}^{2}$ and the Ramsey's RESET test are very similar to those in the previous regressions of the 
same models. Note that these results are robust to other definitions of the labor quality, proxied by the share of skilled labor.

In summary, there is compelling evidence that FDI, in particular that from the U.S. going into non-maquiladora plants, has a positive effect on both TFP and TFP growth. This result is in line with the hypotheses that a positive FDI effect is more likely from investment originating in technologically advanced countries and being of the horizontal rather than the vertical kind. There is no evidence that FDI originating in more distant countries generates more spillovers to local firms and thus has a more positive influence.

Tables $7 \mathrm{a}$ and $7 \mathrm{~b}$ show results using labor productivity, defined as value added per worker, as the dependent variable instead. Using this simpler measure of productivity, the regressions additionally include the capital-labor ratio and capital stock as demonstrated in (15). In all regressions, the coefficients on these two variables are significant and of the expected sign. All other controls are identical, except that baseline (1993) productivity is now also labor productivity.

The results for the effect of FDI are weaker than with TFP. Total FDI exerts a significantly positive effect on labor productivity only in the first model, as does maquiladora FDI. The fixed effect models have positive coefficients on U.S., as in the TFP regressions, though the magnitude is cut in half. Thus, one can conclude that there is less evidence of a positive effect of FDI on labor productivity and that it is smaller than its effect on TFP. Another stark difference to the TFP results is that when fixed effects are included, all industry level variables except labor quality are strongly statistically significant. All but concentration have the expected signs. It may be that while the proxy, the number of plants in an industry, does indeed matter, it is a poor proxy for market concentration, even after controlling for scale. Unfortunately, no better control is available for all years at this time. Finally note that the $\mathrm{R}^{2}$ are very high (0.94 and up), while some of the Ramsey tests appear to indicate the possibility of omitted variables. This case illustrates the low power of the test.

While the differing results with respect to the two productivities certainly warrant further research, they do underscore that measured productivity effects from globalization crucially depend on which productivity measure is used. Table 5 shows that, on average, measured TFP as well as labor productivity fell over the sample period, the latter by more. Labor productivity, while easily calculated and often available for many sectors, years and countries, is perhaps a relatively poor measure and we ought to have more confidence in the relevance of the sophisticated TFP measure used here. The results also demonstrate that aggregate analyses such as Ramirez (2006), who 
finds a positive effect of FDI per worker on labor productivity growth in Mexico, mask underlying industry trends.

Next, I turn to examining the impact of FDI on average remuneration, results of which are in Tables $8 \mathrm{a}$ and $8 \mathrm{~b}$. Remuneration is defined as total payments to labor, inclusive of benefits. This is then divided by the total labor force. The controls are the same as those for labor productivity, as shown in (16). Using total FDI, only the first model shows a significantly positive effect of FDI. The results in Table 8a are identical to those in Table $7 \mathrm{a}$ where the dependent variable is labor productivity, seemingly confirming that over the sample period, wages reflect productivity. However, splitting the sample (see Table 8b), the coefficient on maquiladora FDI is significantly negative in the fixed effect models as is that on US. FDI. This result is important since it provides evidence that FDI can have differential effects depending on its source as well as its destination. Maquiladora operations tend to be more unskilled-labor intensive than non-maquiladora ones, implying that FDI into them raises the relative demand for unskilled labor. Indeed, when skilled and unskilled wages are investigated separately in Tables 9 and 10, respectively, maquiladora FDI is shown to have a negative effect on skilled wages only. We should note, however, that the magnitude is quite small. For example, in regression (8), Table 8b, a ten percent increase in FDI is associated with a 0.19 percent decrease in average remuneration.

Most control variables that are significant are sensible. For example, scale is often significantly positive, confirming that larger plants tend to pay higher wages. In the changes regressions, the change in the share of skilled workers is large and positive, as one would expect since a shift towards a more skill-intensive labor mix should raise average compensation. One problem in looking at wage effects over this period of time is the large drop in real wages as a result of the peso crisis. As can be seen in Table 5, this drop is large enough to result in a negative average wage change in the sample, even though the 1998-2003 change is positive. It can also be seen that the drop is comparable for skilled and unskilled workers.

As mentioned above, I examine the effect of FDI on average compensation for skilled and unskilled workers separately. In order to conserve space, Tables 9 (for skilled workers) and 10 (for unskilled workers) contain only the coefficients on the FDI variables and omit those on the controls, which are identical to those used in the average total compensation regressions. The results for skilled wages are very similar to the results for overall wages, whereas only U.S. FDI in regression (11) is marginally significant, and negative, for unskilled wages. Thus, there is no evidence of positive average wage effects of FDI, despite some evidence of positive productivity 
effects. This overall effect is in line with earlier findings, e.g. Aitken et al. (1996) for both Mexico and Venezuela. As in their study, the lack of an overall effect could be masking very different effects on foreign-owned versus domestically owned firms, which cannot be ascertained in this study.

Finally, Table 11 checks whether there is an effect of FDI on wage inequality. I now use the share of total compensation accruing to skilled workers as the dependent variable. Again, all control variables are the same as in the other wage regressions and their coefficients are sensible, but omitted in order to conserve space. Note that a positive coefficient on FDI is consistent with FDI contributing to wage inequality. Significantly positive coefficients appear when we include the initial 1993 skilled remuneration share for total and non-maquiladora FDI and marginally for non-U.S. FDI. Conversely, the fixed effect models show a negative coefficient on maquiladora FDI. Again, this is consistent with theoretical expectations. As maquiladora FDI tends to raise the relative demand for unskilled labor and non-maquiladora FDI the relative demand for skilled labor, the two should have opposing effects on wage inequality. However, since maquiladora FDI was shown to reduce overall wages by reducing skilled workers' wages, this result is not a positive one. More generally, we emphasize that, of course, rising inequality is not inconsistent with absolute improvements in both skilled and unskilled wages. As discussed above, this is true for the time period between the 1999 and 2004 Census years, but not the time between the 1994 and 1999 Census years due to the peso crisis.

To sum up, the results of this study indicate that FDI appears to have a positive effect on industry productivity, at least when measured as total factor productivity, but that notwithstanding, workers' wages are either not or negatively affected, largely in association with increased maquiladora investment. Thus, it appears that productivity and wages have been diverging over the NAFTA period. The origin of FDI also often plays a role, with U.S. FDI largely driving productivity as well as wage effects. The results provide some support for the hypothesis that horizontal FDI is a more likely source of beneficial productivity effects. The hypothesis that more distant FDI is more likely to source locally and thus have a more positive effect cannot be confirmed. The likely reason is the dominance of U.S. FDI in the Mexican case. 


\section{Conclusion}

There is great interest in the effects of NAFTA on various economic indicators in Mexico, such as productivity or wages. Naturally, it is difficult to disentangle NAFTA from other factors affecting the Mexican economy since its inception. Thus, the goal of this study is more modest in documenting the effect of increased foreign direct investment inflows into Mexico, which the literature has well established, on productivity and wages over the years since NAFTA was enacted without ascribing these to the agreement per se. An important feature of the study is that I pay attention to the source country and the destination industry of FDI. They are shown to matter, consistent with theoretical hypotheses, although I cannot confirm that FDI from more distant countries has a larger positive effect on TFP or labor productivity. This may be due to the dominant role of the United States as a source country of investment as well as considerable export-platform investment by other countries, suggesting that they all take advantage of the evolved vertically integrated North American production network. However, positive productivity effects stem from non-maquiladora FDI, which is more likely to be of the horizontal kind. Wages, on the other hand, are at best unaffected, but may be negatively affected by FDI, particularly into maquiladoras. Since such investments largely tend to reduce skilled wages, however, they help dampen income inequality.

Other contributions of this study are that I cover a longer time period, a full decade since the inception of NAFTA, and use data from the Industrial Census, which contains comprehensive information on economic activity in Mexico, unlike the annual surveys, which oversample large

firms. Ideally, I would like to have used plant level data from these Censuses, but due to extremely strict confidentiality requirements imposed by Mexico's statistical agency, this is not possible.

Still, to the extent that policy makers care about industry and aggregate effects of foreign investment, the study makes an important contribution to the discussion of the efficacy of foreign direct investment. Policies that increase a country's openness to FDI and seek to attract more are bolstered by the results in the sense that there is evidence that a greater foreign presence enhances efficiency. However, a positive effect on wages cannot be ascertained. While this result is not encouraging, it is possible that the recent disconnect between productivity and wages may have little to do with FDI. It could be a result of the specific time period studied, which was characterized by a severe economic crisis from which wages in particular appear not to have recovered. That is, while wages may well reflect productivity in the long run, it may be several more years before this happens. Secondly, other factors, such as a diminished power of unions which has been observed 
in Mexico and elsewhere over the last two decades, could be driving a wedge between productivity and wage changes and I have not accounted for those in the empirical analysis.

Future work in this area, and in particular on Mexico, should attempt to explore the specific channels through which FDI affects industry productivity. For example, data on R\&D and technology expenditures could shed light on the question of technological versus other spillovers. Also, observers of the Mexican economy note the regional disparities in economic development and foreign investment, which in part are tied to the location of maquiladoras. More detailed regional data would help shed light on whether FDI benefits are indeed geographically limited and to what extent. Clearly, these are important issues to be analyzed, but are beyond the scope of the present study. 


\section{References}

[1] Aitken, B.J., Harrison, A.E., 1999. Do Domestic Firms Benefit from Direct Foreign Investment? Evidence from Venezuela. American Economic Review 89, 605-18.

[2] Aitken, B.J., Harrison, A.E., Lipsey, R.E., 1996. Wages and Foreign Ownership. A Comparative Study of Mexico, Venezuela, and the United States. Journal of International Economics 40, 345-71.

[3] Alfaro, L., Rodríguez-Clare, A., 2004. Multinationals and Linkages: An Empirical Investigation. Economía 4(2), 113-56.

[4] Bernard, A., Eaton, J., Jensen, J., Kortum, S., 2003. Plants and Productivity in International Trade. American Economic Review 93(4), 1268-90.

[5] Bernard, A.B., Robertson, R., Schott, P.K., 2004. Is Mexico a Lumpy Country? National Bureau of Economic Research Working Paper 10898.

[6] Blomström, M., 1986. Foreign Investment and Productive Efficiency: The Case of Mexico. Journal of Industrial Economics 35, 97-110.

[7] Blomström, M., Kokko, A., 1998. Multinational Corporations and Spillovers. Journal of Economic Surveys 12(2), 1-31.

[8] Blomström, M., Wolff, E.N., 1994. Multinational Corporations and Productivity Convergence in Mexico. In: Convergence of Productivity: Cross National Studies and Historical Evidence, Baumol, W., Nelson, R., and Wolff, N. (eds.). Oxford University Press: Oxford.

[9] Borensztein, E., De Gregorio, J., Lee, J-W., 1998. How Does Foreign Direct Investment Affect Economic Growth? Journal of International Economics 45, 115-35.

[10] Cuevas, A., Messmacher, M., Werner, A., 2005. Foreign Direct Investment in Mexico since the Approval of NAFTA. World Bank Economic Review 19, 473-88.

[11] De Mello, L.R., 1999. Foreign Direct Investment-Led Growth: Evidence from Time Series and Panel Data. Oxford Economic Papers 51, 133-51.

[12] Esquivel, G., Rodríguez-López, J.A., 2003. Technology, trade, and wage inequality in Mexico before and after NAFTA. Journal of Development Economics 72, 543-65.

[13] Feenstra, R.C., Hanson, G.H., 1997. Foreign Direct Investment and Relative Wages: Evidence from Mexico's Maquiladoras. Journal of International Economics 42, 371-393.

[14] Feliciano, Z.M., 2001. Workers and Trade Liberalization: The Impact of Trade Reforms in Mexico on Wages and Employment. Industrial and Labor Relations Review 55, 95-115.

[15] Görg, H., Greenaway, D., 2004. Much Ado About Nothing? Do Domestic Firms Really Benefit from Foreign Direct Investment? World Bank Research Observer 19, 171-86.

[16] Görg, H., Strobl, E., 2001. Multinational Companies and Productivity Spillovers: A MetaAnalysis. Economic Journal 111, 723-39. 
[17] Griffiths, D., Sapsford, D., 2004. Foreign Direct Investment in Mexico. In: Foreign Direct Investment: Six Country Case Studies, Wei, Y.A., Balasubramanyam, V.N. (Eds.). New Horizons in International Business. Cheltenham, U.K. and Northampton, MA: Elgar, 103-27.

[18] Grubel, H.G., Lloyd, P.J., 1971. The Empirical Measurement of Intra-Industry Trade. Economic Record 47, 494-517.

[19] Grubel, H.G., Lloyd, P.J., 1975. Intra-Industry Trade. London: Macmillan.

[20] Hanson, G.H., 2003. What Has Happened to Wages in Mexico Since NAFTA? Implications for Hemispheric Free Trade. National Bureau of Economic Research Working Paper 9563.

[21] Hanson, G.H., 2007. Globalization, Labor Income, and Poverty in Mexico. In: Ann Harrison (Ed.) Globalization and Poverty. Chicago: University of Chicago Press and the National Bureau of Economic Research, 417-456.

[22] Hanson, G.H., Harrison, A., 1999. Trade Liberalization and Wage Inequality in Mexico. Industrial and Labor Relations Review 52(2), 271-88.

[23] Javorcik, B.S., Saggi, K., Spatareanu, M., 2004. Does It Matter Where You Come From? Vertical Spillovers from Foreign Direct Investment and the Nationality of Investors. World Bank Policy Research Working Paper 3449.

[24] Jordaan, J.A., 2005. Determinants of FDI-Induced Externalities: New Empirical Evidence for Mexican Manufacturing Industries. World Development 33, 2103-18.

[25] Leamer, E., 1998. In Search of Stolper-Samuelson Linkages between International Trade and Lower Wages. In: Collins, S. (Ed.), Imports, Exports and the American Worker, Brookings Institution, 141-202.

[26] Levinsohn, J., Petrin, A., 2003. Estimating Production Functions Using Inputs to Control for Unobservables. The Review of Economic Studies 70, 317-42.

[27] Levy Yeyati, E., Panizza, U., Stein, E., 2007. The Cyclical Nature of North-South FDI Flows. Journal of International Money and Finance 26, 104-30.

[28] Lim, L., 2001. The Globalization Debate: Issues and Challenges. Geneva: International Labour Organisation.

[29] Lipsey, R.E., 2002. Home and Host Country Effects of FDI. National Bureau of Economic Research Working Paper 9293, October.

[30] López-Córdova, J.E., 2003. NAFTA and Manufacturing Productivity in Mexico. Economía $4(1), 55-88$.

[31] Markusen, J.R. 2002. Multinational Firms and the Theory of International Trade. The MIT Press, Cambridge.

[32] Montes-Rojas, G., Santamaria, M., 2007. Sources of Productivity Growth: Evidence from the Mexican Manufacturing Sector. North American Journal of Economics and Finance 18, 263-78.

[33] Olley, G.S., Pakes, A., 1996. The Dynamics of Productivity in the Telecommunications Equipment Industry. Econometrica 64, 1263-97. 
[34] Petrin, A., Levinsohn, J., Poi, B.P., 2004. Production Function Estimation in STATA Using Inputs to Control for Unobservables. The STATA Journal 4, 113-23.

[35] Ramirez, M.D., 2006. Is Foreign Direct Investment Beneficial for Mexico? An Empirical Analysis, 1960-2001. World Development 34(5), 802-17.

[36] Robertson, R., 2006. Are Mexican and U.S. Workers Complements or Substitutes? Mimeo, Macalester College.

[37] Rodríguez-Clare, A., 1996. Multinationals, Linkages, and Economic Development. American Economic Review 86, 852-73.

[38] Taylor, K., Driffield, N., 2005. Wage Inequality and the Role of Multinationals: Evidence from UK Panel Data. Labour Economics 12, 223-49.

[39] Tornell, A., Esquivel, G., 1997. The Political Economy of Mexico's Entry into NAFTA. In: Regionalism versus Multilateral Trade Arrangements, Ito, T., Krueger, A.O. (eds.). Chicago: University of Chicago Press.

[40] UNCTAD. World Investment Report 2006.

[41] Waldkirch, A., 2003. The 'New Regionalism' and Foreign Direct Investment: The Case of Mexico. Journal of International Trade and Economic Development 12, 151-84.

[42] Yeaple, S.R., 2003. The Complex Integration Strategies of Multinationals and Cross Country Dependencies in the Structure of Foreign Direct Investment, Journal of International Economics 60, 293-314. 
Table 1: FDI Flows into Mexico 1994-2005, by Sector, in Millions of U.S. \$

\begin{tabular}{|c|c|c|c|c|c|c|c|}
\hline Year & Total & $\begin{array}{c}\text { Manu- } \\
\text { facturing }\end{array}$ & $\begin{array}{l}\text { of which } \\
\text { Maquil. }\end{array}$ & Services & $\begin{array}{c}\text { of which } \\
\text { Trade }\end{array}$ & $\begin{array}{l}\text { Agri- } \\
\text { culture }\end{array}$ & Mining \\
\hline 1994 & 10,630 & 6,195 & 893 & 4,327 & 1,247 & 10.0 & 97.8 \\
\hline 1995 & 8,337 & 4,851 & 1,363 & 3,398 & 1,012 & 9.48 & 79.0 \\
\hline 1996 & 7,823 & 4,814 & 1,415 & 2,891 & 739 & 33.4 & 83.8 \\
\hline 1997 & 12,079 & 7,298 & 1,676 & 4,640 & 1,868 & 10.0 & 131 \\
\hline 1998 & 8,325 & 5,003 & 2,105 & 3,244 & 1,038 & 29.1 & 49.4 \\
\hline 1999 & 13,565 & 9,137 & 2,770 & 4,207 & 1,409 & 82.5 & 138 \\
\hline 2000 & 17,507 & 9,879 & 2,980 & 7,338 & 2,432 & 91.6 & 199 \\
\hline 2001 & 27,059 & 5,492 & 2,172 & 21,478 & 2,224 & 61.2 & 28.5 \\
\hline 2002 & 18,150 & 7,582 & 2,043 & 10,234 & 1,739 & 92.6 & 242 \\
\hline 2003 & 13,773 & 6,204 & 1,961 & 7,484 & 1,394 & 10.6 & 74.6 \\
\hline 2004 & 18,361 & 9,290 & 2,474 & 9,185 & 1,175 & 14.8 & 141.9 \\
\hline 2005 & 13,745 & 7,792 & 2,821 & 5,955 & 2,539 & 5.2 & -7.71 \\
\hline 1994-2005 & 169,626 & 83,536 & 24,672 & 84,382 & 18,815 & 450.5 & 1,257 \\
\hline
\end{tabular}

Source (for Tables 1-4): Secretaría de Economía, Mexico, and author's calculations.

Table 2: FDI Source Countries 1994-2005, Share as Percent of Total

\begin{tabular}{ccccccc}
\hline \hline Year & $\begin{array}{c}\text { United } \\
\text { States }\end{array}$ & $\begin{array}{c}\text { United } \\
\text { Kingdom }\end{array}$ & $\begin{array}{c}\text { European } \\
\text { Union }\end{array}$ & Japan & OECD & $\begin{array}{c}\text { Developing } \\
\text { Countries }\end{array}$ \\
\hline 1994 & 46.9 & 5.6 & 18.1 & 5.9 & 78.7 & 21.2 \\
1995 & 65.9 & 2.7 & 22.1 & 1.9 & 94.4 & 4.3 \\
1996 & 67.5 & 1.1 & 14.7 & 1.8 & 92.1 & 6.8 \\
1997 & 61.5 & 15.2 & 26.3 & 2.9 & 94.5 & 5.5 \\
1998 & 65.6 & 2.2 & 24.7 & 1.2 & 95.6 & 4.4 \\
1999 & 54.3 & -1.4 & 28.5 & 9.1 & 97.7 & 2.3 \\
2000 & 71.5 & 1.6 & 18.2 & 2.4 & 97.1 & 2.9 \\
2001 & 77.8 & 0.5 & 15.5 & 0.7 & 97.3 & 2.7 \\
2002 & 65.8 & 6.9 & 26.9 & 0.3 & 97.2 & 2.8 \\
2003 & 59.2 & 7.7 & 33.3 & 0.9 & 98.0 & 2.0 \\
2004 & 41.6 & 0.7 & 46.2 & 2.0 & 98.6 & 1.4 \\
2005 & 65.7 & 2.2 & 29.0 & 0.5 & 98.1 & 1.9 \\
$1994-2005$ & 62.8 & 3.5 & 25.6 & 2.3 & 95.8 & 4.1 \\
\hline
\end{tabular}


Table 3: FDI in Selected Manufacturing and Service Sub-Sectors

\begin{tabular}{|c|c|c|c|c|c|c|}
\hline $\begin{array}{l}\text { Sector } \\
\text { (CMAP code in parentheses) }\end{array}$ & $\begin{array}{l}\text { Share* } \\
\text { Overall }\end{array}$ & $\begin{array}{l}\text { Share }^{* *} \\
\text { U.S. }\end{array}$ & $\begin{array}{l}\text { Share** } \\
\text { Canada }\end{array}$ & $\begin{array}{l}\text { Share }^{* *} \\
\text { UK }\end{array}$ & $\begin{array}{l}\text { Share }^{* *} \\
\text { Spain }\end{array}$ & $\begin{array}{l}\text { Share** }^{* *} \\
\text { Japan }\end{array}$ \\
\hline Food and Tobacco (31) & 18.5 & 48.8 & 4.0 & 13.6 & 0.7 & 0.1 \\
\hline \multicolumn{7}{|l|}{ Textiles, Apparel, } \\
\hline Footwear and Leather (32) & 3.7 & 79.4 & 0.8 & 3.1 & 2.1 & 0.1 \\
\hline Wood Products (33) & 0.4 & 90.9 & 5.9 & 0.0 & 0.0 & 0.0 \\
\hline \multicolumn{7}{|l|}{ Paper, Printing and } \\
\hline Publishing (34) & 2.4 & 48.3 & 13.9 & 1.7 & 4.3 & 0.0 \\
\hline \multicolumn{7}{|l|}{ Chemicals and } \\
\hline Pharmaceuticals (35) & 14.5 & 64.1 & 2.7 & -0.7 & 8.4 & 0.5 \\
\hline Clay, Glass, Cement, etc. (36) & 1.9 & 22.2 & 13.6 & 2.9 & 8.3 & 0.1 \\
\hline \multicolumn{7}{|l|}{ Nonferrous Metals, } \\
\hline Iron and Steel (37) & 3.6 & 15.4 & 0.6 & 1.4 & 2.5 & -0.1 \\
\hline \multicolumn{7}{|l|}{ Metals, Electrical Machinery, } \\
\hline Automobiles (38) & 48.5 & 67.5 & 3.1 & 0.6 & 1.7 & 8.7 \\
\hline Electricity and Water (4) & 2.1 & 4.2 & 0.0 & 0.1 & 82.0 & 0.9 \\
\hline Construction (5) & 2.0 & 51.7 & 0.8 & 4.3 & 23.1 & 0.5 \\
\hline Wholesale Trade (61) & 12.8 & 66.5 & 1.9 & 0.9 & 5.1 & 1.8 \\
\hline Retail Trade (62) & 9.5 & 82.7 & 0.2 & 0.0 & 0.1 & 0.2 \\
\hline Transportation (71) & 1.3 & 57.2 & 0.3 & 0.0 & 0.4 & 0.0 \\
\hline Communications (72) & 9.0 & 67.0 & 0.6 & 8.5 & 37.4 & -0.1 \\
\hline Banking and Insurance (81) & 42.4 & 66.2 & 2.0 & 5.7 & 18.0 & 0.0 \\
\hline \multicolumn{7}{|l|}{ Hotels, Bars and } \\
\hline Restaurants (93) & 5.8 & 69.6 & 4.5 & 0.8 & 10.9 & 0.5 \\
\hline \multicolumn{7}{|l|}{ Business and Personal } \\
\hline Services $(95)$ & 7.6 & 44.1 & 7.7 & 3.4 & 7.5 & -0.4 \\
\hline
\end{tabular}


Table 4: FDI-Intra-Industry Trade (IIT) Index Correlations

\begin{tabular}{|c|c|c|c|c|c|c|}
\hline & \multicolumn{3}{|c|}{ All Observations } & \multicolumn{3}{|c|}{ Using U.S. IIT } \\
\hline & Corr. & p-value & Obs. & Corr. & $\mathrm{p}$-value & Obs. \\
\hline Total FDI- & & & & & & \\
\hline IIT, lagged & 0.08 & 0.00 & 16,954 & 0.01 & 0.03 & 28,890 \\
\hline Maquila FDI - & & & & & & \\
\hline IIT, lagged & 0.11 & 0.00 & 16,954 & 0.03 & 0.00 & 28,890 \\
\hline Non-Maquila FDI - & & & & & & \\
\hline IIT, lagged & 0.05 & 0.00 & 16,954 & 0.00 & 0.91 & 28,890 \\
\hline Total FDI- & & & & & & \\
\hline$\Delta \mathrm{IIT}$, lagged & 0.01 & 0.09 & 14,629 & 0.02 & 0.01 & 28,890 \\
\hline Maquila FDI - & & & & & & \\
\hline$\Delta \mathrm{IIT}$, lagged & 0.00 & 0.93 & 14,629 & 0.00 & 0.77 & 28,890 \\
\hline Non-Maquila FDI - & & & & & & \\
\hline$\Delta \mathrm{IIT}$, lagged & 0.02 & 0.05 & 14,629 & 0.02 & 0.00 & 28,890 \\
\hline Total FDI- & & & & & & \\
\hline IIT 1993 & 0.11 & 0.00 & 2,250 & 0.01 & 0.50 & 4,680 \\
\hline Maquila FDI - & & & & & & \\
\hline IIT 1993 & 0.12 & 0.00 & 2,250 & 0.04 & 0.01 & 4,680 \\
\hline Non-Maquila FDI - & & & & & & \\
\hline IIT 1993 & 0.07 & 0.00 & 2,250 & -0.01 & 0.40 & 4,680 \\
\hline
\end{tabular}

Notes: Simple pair-wise correlations (Corr.). Obs.: Number of observations.

The top two thirds of the table use all available annual observations.

The bottom third of the table uses total post-1994 FDI.

The results on the right side of the table use IIT computed from U.S. data. 
Table 5: Summary Statistics

\begin{tabular}{|c|c|c|c|c|c|}
\hline Variable & Mean & Median & Stdev. & Min & Max \\
\hline TFP & 1.529 & 1.582 & 0.446 & 0.474 & 2.804 \\
\hline$\Delta \mathrm{TFP}$ & -0.204 & -0.201 & 0.354 & -1.085 & 0.542 \\
\hline Labor Productivity & 2.711 & 2.724 & 0.758 & 0.877 & 4.657 \\
\hline$\Delta$ Labor Productivity & -0.624 & -0.802 & 0.601 & -1.863 & 0.385 \\
\hline Wages Per Worker & 1.669 & 1.762 & 0.602 & -0.095 & 3.099 \\
\hline$\Delta$ Wages Per Worker & -0.725 & -0.863 & 0.688 & -1.867 & 0.436 \\
\hline Wages Per Skilled Worker & 2.259 & 2.313 & 0.403 & 0.751 & 3.091 \\
\hline$\Delta$ Wages Per Skilled Worker & -0.590 & -0.687 & 0.763 & -1.897 & 0.823 \\
\hline Wages Per Unskilled Worker & 1.272 & 1.245 & 0.312 & 0.626 & 2.056 \\
\hline$\Delta$ Wages Per Unskilled Worker & -0.608 & -0.678 & 0.779 & -1.604 & 0.429 \\
\hline Unweighted FDI & 19.02 & 19.14 & 2.295 & 6.049 & 22.74 \\
\hline Distance Weighted FDI & 13.49 & 13.41 & 0.504 & 12.67 & 14.87 \\
\hline Maquila FDI & 15.15 & 16.60 & 5.883 & 0 & 21.56 \\
\hline Non-maquila FDI & 18.63 & 18.97 & 2.374 & 6.049 & 22.60 \\
\hline U.S. FDI & 18.43 & 18.88 & 2.406 & 6.049 & 22.07 \\
\hline Non-U.S. FDI & 17.35 & 17.84 & 3.347 & 0 & 22.03 \\
\hline Share Skilled Workers & 0.414 & 0.406 & 0.137 & 0.036 & 0.810 \\
\hline$\Delta$ Share Skilled Workers & -0.029 & -0.028 & 0.073 & -0.298 & 0.112 \\
\hline Average Plant Size & 6.974 & 7.146 & 1.946 & 2.754 & 11.18 \\
\hline$\Delta$ Average Plant Size & -0.664 & -0.756 & 0.709 & -2.330 & 0.877 \\
\hline Number of Plants & 7.752 & 7.794 & 1.573 & 3.178 & 11.06 \\
\hline$\Delta$ Number of Plants & 0.131 & 0.166 & 0.455 & -1.120 & 1.209 \\
\hline Capital-Labor Ratio & 2.905 & 2.856 & 1.008 & 1.064 & 5.685 \\
\hline$\Delta$ Capital-Labor Ratio & -0.630 & -0.615 & 0.607 & -2.065 & 0.780 \\
\hline Capital & 13.86 & 13.82 & 1.119 & 11.05 & 16.46 \\
\hline$\Delta$ Capital & -0.543 & -0.552 & 0.544 & -1.964 & 0.966 \\
\hline 1993 TFP & 1.903 & 1.972 & 0.441 & 1.121 & 2.974 \\
\hline 1993 Labor Productivity & 3.896 & 3.850 & 0.710 & 2.400 & 5.324 \\
\hline 1993 Remuneration Per Worker & 3.073 & 3.107 & 0.641 & 1.313 & 4.250 \\
\hline 1993 Remuneration Per Skilled Worker & 3.499 & 3.516 & 0.423 & 2.068 & 4.349 \\
\hline 1993 Remuneration Per Unskilled Worker & 2.560 & 2.498 & 0.361 & 1.976 & 3.407 \\
\hline
\end{tabular}

Note: All non-share variables in logs (or log changes) 
Table 6a: FDI and Total Factor Productivity: Total and Distance Weighted FDI

\begin{tabular}{|c|c|c|c|c|c|c|}
\hline Dependent Variable & $\begin{array}{l}\text { TFP } \\
(1)\end{array}$ & $\begin{array}{l}\text { TFP } \\
(2)\end{array}$ & $\begin{array}{c}\Delta \mathrm{TFP} \\
(3)\end{array}$ & $\begin{array}{c}\text { TFP } \\
(4)\end{array}$ & $\begin{array}{l}\text { TFP } \\
(5)\end{array}$ & $\begin{array}{c}\Delta \text { TFP } \\
(6)\end{array}$ \\
\hline Unweighted FDI & $\begin{array}{c}0.004 \\
(0.010)\end{array}$ & $\begin{array}{c}0.050 * * \\
(0.025)\end{array}$ & $\begin{array}{c}0.158^{* * *} \\
(0.049)\end{array}$ & & & \\
\hline Distance Weighted FDI & & & & $\begin{array}{l}-0.013 \\
(0.055)\end{array}$ & $\begin{array}{c}0.032 \\
(0.083)\end{array}$ & $\begin{array}{c}0.115 \\
(0.173)\end{array}$ \\
\hline$(\Delta)$ Labor Quality & $\begin{array}{c}0.291 \\
(0.280)\end{array}$ & $\begin{array}{l}-0.474 \\
(0.599)\end{array}$ & $\begin{array}{l}-0.847 \\
(0.796)\end{array}$ & $\begin{array}{c}0.276 \\
(0.284)\end{array}$ & $\begin{array}{l}-0.020 \\
(0.617)\end{array}$ & $\begin{array}{c}0.471 \\
(0.643)\end{array}$ \\
\hline$(\Delta)$ Scale & $\begin{array}{c}0.087^{* * *} \\
(0.032)\end{array}$ & $\begin{array}{c}0.254 \\
(0.169)\end{array}$ & $\begin{array}{c}0.067 \\
(0.202)\end{array}$ & $\begin{array}{c}0.092^{* * *} \\
(0.031)\end{array}$ & $\begin{array}{c}0.252 \\
(0.174)\end{array}$ & $\begin{array}{c}0.048 \\
(0.205)\end{array}$ \\
\hline$(\Delta)$ Concentration & $\begin{array}{l}0.074^{*} \\
(0.044)\end{array}$ & $\begin{array}{c}0.126 \\
(0.163)\end{array}$ & $\begin{array}{l}-0.201 \\
(0.258)\end{array}$ & $\begin{array}{l}0.076^{*} \\
(0.044)\end{array}$ & $\begin{array}{c}0.119 \\
(0.168)\end{array}$ & $\begin{array}{l}-0.202 \\
(0.275)\end{array}$ \\
\hline 1993 TFP & $\begin{array}{c}0.662^{* * *} \\
(0.076)\end{array}$ & & & $\begin{array}{c}0.667^{* * *} \\
(0.075)\end{array}$ & & \\
\hline Fixed Effects? & No & Yes & Yes & No & Yes & Yes \\
\hline Observations & 92 & 92 & 92 & 92 & 92 & 92 \\
\hline $\mathrm{R}^{2}$ & 0.67 & 0.93 & 0.64 & 0.67 & 0.92 & 0.60 \\
\hline $\operatorname{RESET~} \mathrm{F}(\cdot)$ & 1.61 & 1.27 & 0.23 & 1.58 & 1.91 & 0.45 \\
\hline Prob. $>$ F & 0.19 & 0.30 & 0.87 & 0.20 & 0.15 & 0.72 \\
\hline
\end{tabular}

Note: All regressions include a 2003 dummy (not reported). Robust standard errors in parentheses. All independent variables except FDI are in changes in columns (3) and (6).

RESET is Ramsey's RESET test for omitted variables, H0: no omitted variables.

$*, * *, * * *$ denote significance at the ten, five, and one percent level, respectively. 
Table 6b: FDI and Total Factor Productivity: Maquila, Non-Maquila, U.S., Non-U.S. FDI

\begin{tabular}{|c|c|c|c|c|c|c|}
\hline Dependent Variable & TFP & TFP & $\Delta \mathrm{TFP}$ & TFP & TFP & $\Delta \mathrm{TFP}$ \\
\hline & (7) & $(8)$ & (9) & $(10)$ & (11) & $(12)$ \\
\hline \multirow[t]{2}{*}{ Maquila FDI } & $0.010^{* *}$ & -0.001 & -0.005 & & & \\
\hline & $(0.004)$ & $(0.009)$ & $(0.014)$ & & & \\
\hline \multirow[t]{2}{*}{ Non-maquila FDI } & -0.008 & $0.062^{* *}$ & $0.177^{* * *}$ & & & \\
\hline & $(0.013)$ & $(0.029)$ & $(0.046)$ & & & \\
\hline \multirow[t]{2}{*}{ U.S. FDI } & & & & 0.005 & 0.043 & $0.122^{* * *}$ \\
\hline & & & & $(0.015)$ & $(0.026)$ & $(0.036)$ \\
\hline \multirow[t]{2}{*}{ Non-U.S. FDI } & & & & 0.001 & 0.011 & 0.034 \\
\hline & & & & $(0.011)$ & $(0.036)$ & $(0.070)$ \\
\hline \multirow[t]{2}{*}{$(\Delta)$ Labor Quality } & $0.509^{*}$ & -0.153 & -0.235 & 0.312 & -0.415 & -0.625 \\
\hline & $(0.302)$ & $(0.683)$ & $(0.755)$ & $(0.288)$ & $(0.619)$ & $(0.716)$ \\
\hline \multirow[t]{2}{*}{$(\Delta)$ Scale } & $0.089^{* * *}$ & 0.241 & 0.068 & $0.084^{* * *}$ & 0.247 & 0.057 \\
\hline & $(0.033)$ & $(0.173)$ & $(0.202)$ & $(0.032)$ & $(0.172)$ & $(0.203)$ \\
\hline \multirow[t]{2}{*}{$(\Delta)$ Concentration } & $0.077^{*}$ & 0.137 & -0.175 & $0.073^{*}$ & 0.117 & -0.205 \\
\hline & $(0.044)$ & $(0.161)$ & $(0.260)$ & $(0.044)$ & $(0.161)$ & $(0.265)$ \\
\hline \multirow[t]{2}{*}{1993 TFP } & $0.649^{* * *}$ & & & $0.658^{* * *}$ & & \\
\hline & $(0.073)$ & & & $(0.077)$ & & \\
\hline Fixed Effects? & No & Yes & Yes & No & Yes & Yes \\
\hline Observations & 92 & 92 & 92 & 92 & 92 & 92 \\
\hline $\mathrm{R}^{2}$ & 0.68 & 0.93 & 0.65 & 0.67 & 0.93 & 0.64 \\
\hline RESET F $(\cdot)$ & 1.62 & 1.38 & 0.30 & 1.65 & 0.66 & 0.29 \\
\hline Prob. > F & 0.19 & 0.27 & 0.82 & 0.18 & 0.58 & 0.83 \\
\hline
\end{tabular}

Note: All regressions include a 2003 dummy (not reported). Robust standard errors in parentheses. RESET is Ramsey's RESET test for omitted variables, H0: no omitted variables.

All independent variables except FDI are in changes in columns (9) and (12).

$*, * *, * * *$ denote significance at the ten, five, and one percent level, respectively. 
Table 7a: FDI and Labor Productivity: Total and Distance Weighted FDI

\begin{tabular}{|c|c|c|c|c|c|c|}
\hline Dependent Variable & $\begin{array}{l}\text { Prod. } \\
(1)\end{array}$ & $\begin{array}{l}\text { Prod. } \\
(2)\end{array}$ & $\begin{array}{c}\Delta \text { Prod. } \\
(3)\end{array}$ & $\begin{array}{l}\text { Prod. } \\
(4)\end{array}$ & $\begin{array}{l}\text { Prod. } \\
(5)\end{array}$ & $\begin{array}{c}\Delta \text { Prod. } \\
(6)\end{array}$ \\
\hline Unweighted FDI & $\begin{array}{c}0.025^{* *} \\
(0.010)\end{array}$ & $\begin{array}{c}0.002 \\
(0.024)\end{array}$ & $\begin{array}{c}0.025 \\
(0.052)\end{array}$ & & & \\
\hline Distance Weighted FDI & & & & $\begin{array}{c}0.017 \\
(0.048)\end{array}$ & $\begin{array}{l}-0.054 \\
(0.052)\end{array}$ & $\begin{array}{l}-0.069 \\
(0.089)\end{array}$ \\
\hline$(\Delta)$ Labor Quality & $\begin{array}{c}0.660^{*} \\
(0.396)\end{array}$ & $\begin{array}{l}-0.137 \\
(0.410)\end{array}$ & $\begin{array}{c}0.187 \\
(0.667)\end{array}$ & $\begin{array}{c}0.607 \\
(0.391)\end{array}$ & $\begin{array}{l}-0.180 \\
(0.371)\end{array}$ & $\begin{array}{c}0.381 \\
(0.469)\end{array}$ \\
\hline$(\Delta)$ Scale & $\begin{array}{c}0.470^{* * *} \\
(0.085)\end{array}$ & $\begin{array}{c}1.067^{* * *} \\
(0.162)\end{array}$ & $\begin{array}{c}1.040^{* * *} \\
(0.211)\end{array}$ & $\begin{array}{c}0.464^{* * *} \\
(0.086)\end{array}$ & $\begin{array}{c}1.093^{* * *} \\
(0.161)\end{array}$ & $\begin{array}{c}1.074^{* * *} \\
(0.224)\end{array}$ \\
\hline$(\Delta)$ Concentration & $\begin{array}{c}0.444^{* * *} \\
(0.099)\end{array}$ & $\begin{array}{c}1.100^{* * *} \\
(0.173)\end{array}$ & $\begin{array}{c}1.084^{* * *} \\
(0.219)\end{array}$ & $\begin{array}{c}0.419^{* * *} \\
(0.098)\end{array}$ & $\begin{array}{c}1.118^{* * *} \\
(0.166)\end{array}$ & $\begin{array}{c}1.122^{* * *} \\
(0.225)\end{array}$ \\
\hline$(\Delta)$ Capital-Labor Ratio & $\begin{array}{c}0.453^{* * *} \\
(0.087)\end{array}$ & $\begin{array}{c}0.984^{* * *} \\
(0.169)\end{array}$ & $\begin{array}{c}1.036^{* * *} \\
(0.288)\end{array}$ & $\begin{array}{c}0.407^{* * *} \\
(0.082)\end{array}$ & $\begin{array}{c}0.981^{* * *} \\
(0.165)\end{array}$ & $\begin{array}{c}1.037^{* * *} \\
(0.195)\end{array}$ \\
\hline$(\Delta)$ Capital & $\begin{array}{c}-0.363^{* * *} \\
(0.103)\end{array}$ & $\begin{array}{c}-1.090^{* * *} \\
(0.182)\end{array}$ & $\begin{array}{c}-1.185^{* * *} \\
(0.205)\end{array}$ & $\begin{array}{c}-0.320^{* * *} \\
(0.100)\end{array}$ & $\begin{array}{c}-1.108^{* * *} \\
(0.178)\end{array}$ & $\begin{array}{c}-1.220^{* * *} \\
(0.216)\end{array}$ \\
\hline 1993 Labor Productivity & $\begin{array}{c}0.246^{* * *} \\
(0.079)\end{array}$ & & & $\begin{array}{c}0.285^{* * *} \\
(0.077)\end{array}$ & & \\
\hline Fixed Effects? & No & Yes & Yes & No & Yes & Yes \\
\hline Observations & 92 & 92 & 92 & 92 & 92 & 92 \\
\hline $\mathrm{R}^{2}$ & 0.94 & 0.99 & 0.96 & 0.94 & 0.99 & 0.96 \\
\hline $\operatorname{RESET~F}(\cdot)$ & 3.08 & 2.12 & 2.78 & 3.74 & 2.30 & 2.77 \\
\hline Prob. $>$ F & 0.03 & 0.12 & 0.06 & 0.01 & 0.10 & 0.06 \\
\hline
\end{tabular}

Note: All regressions include a 2003 dummy (not reported). Robust standard errors in parentheses. RESET is Ramsey's RESET test for omitted variables, H0: no omitted variables.

All independent variables except FDI are in changes in columns (3) and (6).

$*, * *, * * *$ denote significance at the ten, five, and one percent level, respectively. 
Table 7b: FDI and Labor Productivity: Maquila, Non-Maquila, U.S., Non-U.S. FDI

\begin{tabular}{|c|c|c|c|c|c|c|}
\hline Dependent Variable & $\begin{array}{l}\text { Prod. } \\
(7)\end{array}$ & $\begin{array}{l}\text { Prod. } \\
\text { (8) }\end{array}$ & $\begin{array}{c}\Delta \text { Prod. } \\
(9)\end{array}$ & $\begin{array}{l}\text { Prod. } \\
(10)\end{array}$ & $\begin{array}{c}\text { Prod. } \\
(11)\end{array}$ & $\begin{array}{c}\Delta \text { Prod } \\
(12)\end{array}$ \\
\hline Maquila FDI & $\begin{array}{c}0.009 * * \\
(0.004)\end{array}$ & $\begin{array}{c}-0.0003 \\
(0.005)\end{array}$ & $\begin{array}{l}-0.001 \\
(0.010)\end{array}$ & & & \\
\hline Non-maquila FDI & $\begin{array}{c}0.016 \\
(0.012)\end{array}$ & $\begin{array}{c}0.001 \\
(0.026)\end{array}$ & $\begin{array}{c}0.024 \\
(0.052)\end{array}$ & & & \\
\hline U.S. FDI & & & & $\begin{array}{c}0.021 \\
(0.014)\end{array}$ & $\begin{array}{c}0.027^{* *} \\
(0.013)\end{array}$ & $\begin{array}{l}0.058^{*} \\
(0.030)\end{array}$ \\
\hline Non-U.S. FDI & & & & $\begin{array}{c}0.004 \\
(0.010)\end{array}$ & $\begin{array}{l}-0.036 \\
(0.022)\end{array}$ & $\begin{array}{l}-0.053 \\
(0.037)\end{array}$ \\
\hline$(\Delta)$ Labor Quality & $\begin{array}{l}0.710^{*} \\
(0.369)\end{array}$ & $\begin{array}{l}-0.116 \\
(0.440)\end{array}$ & $\begin{array}{c}0.302 \\
(0.599)\end{array}$ & $\begin{array}{c}0.684^{*} \\
(0.398)\end{array}$ & $\begin{array}{l}-0.318 \\
(0.405)\end{array}$ & $\begin{array}{c}0.045 \\
(0.586)\end{array}$ \\
\hline$(\Delta)$ Scale & $\begin{array}{c}0.488^{* * *} \\
(0.081)\end{array}$ & $\begin{array}{c}1.068^{* * *} \\
(0.172)\end{array}$ & $\begin{array}{c}1.033^{* * *} \\
(0.218)\end{array}$ & $\begin{array}{c}0.474^{* * *} \\
(0.085)\end{array}$ & $\begin{array}{c}1.076^{* * *} \\
(0.164)\end{array}$ & $\begin{array}{c}1.044^{* * *} \\
(0.220)\end{array}$ \\
\hline$(\Delta)$ Concentration & $\begin{array}{c}0.470^{* * *} \\
(0.092)\end{array}$ & $\begin{array}{c}1.100^{* * *} \\
(0.180)\end{array}$ & $\begin{array}{c}1.079^{* * *} \\
(0.229)\end{array}$ & $\begin{array}{c}0.451^{* * *} \\
(0.099)\end{array}$ & $\begin{array}{c}1.086^{* * *} \\
(0.169)\end{array}$ & $\begin{array}{c}1.077^{* * *} \\
(0.219)\end{array}$ \\
\hline$(\Delta)$ Capital-Labor Ratio & $\begin{array}{c}0.481^{* * *} \\
(0.082)\end{array}$ & $\begin{array}{c}0.985^{* * *} \\
(0.173)\end{array}$ & $\begin{array}{c}1.028^{* * *} \\
(0.197)\end{array}$ & $\begin{array}{c}0.458^{* * *} \\
(0.088)\end{array}$ & $\begin{array}{c}0.929^{* * *} \\
(0.172)\end{array}$ & $\begin{array}{c}1.004^{* * *} \\
(0.197)\end{array}$ \\
\hline$(\Delta)$ Capital & $\begin{array}{c}-0.392^{* * *} \\
(0.095)\end{array}$ & $\begin{array}{c}-1.091^{* *} \\
(0.189)\end{array}$ & $\begin{array}{c}-1.175^{* * *} \\
(0.218)\end{array}$ & $\begin{array}{c}-0.368^{* * *} \\
(0.104)\end{array}$ & $\begin{array}{c}-1.087^{* * *} \\
(0.109)\end{array}$ & $\begin{array}{c}-1.196^{* * *} \\
(0.210)\end{array}$ \\
\hline 1993 Labor Productivity & $\begin{array}{c}0.249^{* * *} \\
(0.080)\end{array}$ & & & $\begin{array}{c}0.247^{* * *} \\
(0.081)\end{array}$ & & \\
\hline Fixed Effects? & No & Yes & Yes & No & Yes & Yes \\
\hline Observations & 92 & 92 & 92 & 92 & 92 & 92 \\
\hline $\mathrm{R}^{2}$ & 0.94 & 0.99 & 0.96 & 0.94 & 0.99 & 0.97 \\
\hline RESET F $(\cdot)$ & 2.35 & 2.02 & 3.02 & 3.53 & 4.07 & 2.83 \\
\hline Prob. $>$ F & 0.08 & 0.13 & 0.04 & 0.02 & 0.02 & 0.05 \\
\hline
\end{tabular}

Note: All regressions include a 2003 dummy (not reported). Robust standard errors in parentheses. RESET is Ramsey's RESET test for omitted variables, H0: no omitted variables.

All independent variables except FDI are in changes in columns (9) and (12).

$*, * *, * * *$ denote significance at the ten, five, and one percent level, respectively. 
Table 8a: FDI and Wages: Total and Distance Weighted FDI

\begin{tabular}{|c|c|c|c|c|c|c|}
\hline Dependent Variable & $\begin{array}{c}\text { Wages } \\
(1)\end{array}$ & $\begin{array}{c}\text { Wages } \\
(2)\end{array}$ & $\begin{array}{c}\Delta \text { Wages } \\
(3)\end{array}$ & $\begin{array}{c}\text { Wages } \\
(4)\end{array}$ & $\begin{array}{c}\text { Wages } \\
(5)\end{array}$ & $\begin{array}{c}\Delta \text { Wages } \\
(6)\end{array}$ \\
\hline Unweighted FDI & $\begin{array}{c}0.028^{* * *} \\
(0.014)\end{array}$ & $\begin{array}{l}-0.027 \\
(0.025)\end{array}$ & $\begin{array}{l}-0.059 \\
(0.036)\end{array}$ & & & \\
\hline Distance Weighted FDI & & & & $\begin{array}{l}-0.015 \\
(0.044)\end{array}$ & $\begin{array}{c}0.052 \\
(0.085)\end{array}$ & $\begin{array}{c}0.064 \\
(0.121)\end{array}$ \\
\hline$(\Delta)$ Labor Quality & $\begin{array}{c}0.726^{*} \\
(0.380)\end{array}$ & $\begin{array}{c}0.365 \\
(0.512)\end{array}$ & $\begin{array}{c}1.541^{* *} \\
(0.588)\end{array}$ & $\begin{array}{c}0.605 \\
(0.411)\end{array}$ & $\begin{array}{c}0.209 \\
(0.738)\end{array}$ & $\begin{array}{c}1.051 \\
(0.681)\end{array}$ \\
\hline$(\Delta)$ Scale & $\begin{array}{c}0.121 \\
(0.089)\end{array}$ & $\begin{array}{c}0.478^{* * *} \\
(0.138)\end{array}$ & $\begin{array}{c}0.283 \\
(0.175)\end{array}$ & $\begin{array}{c}0.117 \\
(0.087)\end{array}$ & $\begin{array}{c}0.423^{* * *} \\
(0.138)\end{array}$ & $\begin{array}{c}0.229 \\
(0.171)\end{array}$ \\
\hline$(\Delta)$ Concentration & $\begin{array}{c}0.061 \\
(0.104)\end{array}$ & $\begin{array}{c}0.419 * * * \\
(0.155)\end{array}$ & $\begin{array}{c}0.249 \\
(0.195)\end{array}$ & $\begin{array}{c}0.054 \\
(0.103)\end{array}$ & $\begin{array}{c}0.369 \\
(0.155)\end{array}$ & $\begin{array}{c}0.183 \\
(0.187)\end{array}$ \\
\hline$(\Delta)$ Capital-Labor Ratio & $\begin{array}{c}0.003 \\
(0.077)\end{array}$ & $\begin{array}{c}0.451^{* *} \\
(0.191)\end{array}$ & $\begin{array}{c}0.360^{* *} \\
(0.142)\end{array}$ & $\begin{array}{l}-0.038 \\
(0.075)\end{array}$ & $\begin{array}{c}0.433^{* *} \\
(0.169)\end{array}$ & $\begin{array}{c}0.362^{* *} \\
(0.134)\end{array}$ \\
\hline$(\Delta)$ Capital & $\begin{array}{c}0.004 \\
(0.109)\end{array}$ & $\begin{array}{l}-0.350^{*} \\
(0.201)\end{array}$ & $\begin{array}{l}-0.257 \\
(0.158)\end{array}$ & $\begin{array}{c}0.037 \\
(0.106)\end{array}$ & $\begin{array}{l}-0.293 \\
(0.183)\end{array}$ & $\begin{array}{l}-0.200 \\
(0.144)\end{array}$ \\
\hline 1993 Remuneration & $\begin{array}{c}0.534^{* * *} \\
(0.085)\end{array}$ & & & $\begin{array}{c}0.629^{* * *} \\
(0.083)\end{array}$ & & \\
\hline Fixed Effects? & No & Yes & Yes & No & Yes & Yes \\
\hline Observations & 92 & 92 & 92 & 92 & 92 & 92 \\
\hline $\mathrm{R}^{2}$ & 0.91 & 0.98 & 0.98 & 0.91 & 0.98 & 0.97 \\
\hline $\operatorname{RESET~F}(\cdot)$ & 5.98 & 1.59 & 2.91 & 5.69 & 3.43 & 5.13 \\
\hline Prob. $>$ F & 0.00 & 0.21 & 0.05 & 0.00 & 0.03 & 0.01 \\
\hline
\end{tabular}

Note: All regressions include a 2003 dummy (not reported). Robust standard errors in parentheses. RESET is Ramsey's RESET test for omitted variables, H0: no omitted variables.

All independent variables except FDI are in changes in columns (3) and (6).

$*, * *, * * *$ denote significance at the ten, five, and one percent level, respectively. 
Table 8b: FDI and Wages: Maquila, Non-Maquila, U.S., Non-U.S. FDI

\begin{tabular}{|c|c|c|c|c|c|c|}
\hline Dependent Variable & $\begin{array}{c}\text { Wages } \\
(7)\end{array}$ & $\begin{array}{c}\text { Wages } \\
(8)\end{array}$ & $\begin{array}{c}\Delta \text { Wages } \\
(9)\end{array}$ & $\begin{array}{c}\text { Wages } \\
(10)\end{array}$ & $\begin{array}{c}\text { Wages } \\
(11)\end{array}$ & $\begin{array}{c}\Delta \text { Wages } \\
(12)\end{array}$ \\
\hline Maquila FDI & $\begin{array}{c}0.005 \\
(0.005)\end{array}$ & $\begin{array}{c}-0.019^{*} \\
(0.011)\end{array}$ & $\begin{array}{c}-0.026^{*} \\
(0.014)\end{array}$ & & & \\
\hline Non-maquila FDI & $\begin{array}{c}0.024 \\
(0.015)\end{array}$ & $\begin{array}{c}0.004 \\
(0.027)\end{array}$ & $\begin{array}{l}-0.020 \\
(0.038)\end{array}$ & & & \\
\hline U.S. FDI & & & & $\begin{array}{c}0.016 \\
(0.015)\end{array}$ & $\begin{array}{c}-0.056^{* *} \\
(0.021)\end{array}$ & $\begin{array}{c}-0.078^{* *} \\
(0.033)\end{array}$ \\
\hline Non-U.S. FDI & & & & $\begin{array}{c}0.008 \\
(0.012)\end{array}$ & $\begin{array}{c}0.024 \\
(0.027)\end{array}$ & $\begin{array}{c}0.016 \\
(0.035)\end{array}$ \\
\hline$(\Delta)$ Labor Quality & $\begin{array}{c}0.792^{* *} \\
(0.382)\end{array}$ & $\begin{array}{c}0.566 \\
(0.524)\end{array}$ & $\begin{array}{c}1.538^{* *} \\
(0.600)\end{array}$ & $\begin{array}{l}0.739^{*} \\
(0.374)\end{array}$ & $\begin{array}{c}0.579 \\
(0.405)\end{array}$ & $\begin{array}{c}1.660^{* * *} \\
(0.560)\end{array}$ \\
\hline$(\Delta)$ Scale & $\begin{array}{l}0.134^{*} \\
(0.084)\end{array}$ & $\begin{array}{c}0.432^{* * *} \\
(0.147)\end{array}$ & $\begin{array}{c}0.261 \\
(0.173)\end{array}$ & $\begin{array}{c}0.127 \\
(0.088)\end{array}$ & $\begin{array}{c}0.498^{* * *} \\
(0.143)\end{array}$ & $\begin{array}{l}0.296^{*} \\
(0.170)\end{array}$ \\
\hline$(\Delta)$ Concentration & $\begin{array}{c}0.073 \\
(0.099)\end{array}$ & $\begin{array}{c}0.368^{* *} \\
(0.164)\end{array}$ & $\begin{array}{c}0.199 \\
(0.195)\end{array}$ & $\begin{array}{c}0.067 \\
(0.105)\end{array}$ & $\begin{array}{c}0.464^{* * *} \\
(0.154)\end{array}$ & $\begin{array}{c}0.270 \\
(0.191)\end{array}$ \\
\hline$(\Delta)$ Capital-Labor Ratio & $\begin{array}{c}0.018 \\
(0.067)\end{array}$ & $\begin{array}{c}0.418^{* *} \\
(0.185)\end{array}$ & $\begin{array}{c}0.323^{* *} \\
(0.142)\end{array}$ & $\begin{array}{c}0.005 \\
(0.080)\end{array}$ & $\begin{array}{c}0.517^{* * *} \\
(0.184)\end{array}$ & $\begin{array}{c}0.375^{* *} \\
(0.139)\end{array}$ \\
\hline$(\Delta)$ Capital & $\begin{array}{l}-0.011 \\
(0.100)\end{array}$ & $\begin{array}{l}-0.298 \\
(0.196)\end{array}$ & $\begin{array}{l}-0.201 \\
(0.162)\end{array}$ & $\begin{array}{c}0.003 \\
(0.111)\end{array}$ & $\begin{array}{c}-0.384^{*} \\
(0.201)\end{array}$ & $\begin{array}{l}-0.262 \\
(0.160)\end{array}$ \\
\hline 1993 Remuneration & $\begin{array}{c}0.513^{* * *} \\
(0.084)\end{array}$ & & & $\begin{array}{c}0.532^{* * *} \\
(0.087)\end{array}$ & & \\
\hline Fixed Effects? & No & Yes & Yes & No & Yes & Yes \\
\hline Observations & 92 & 92 & 92 & 92 & 92 & 92 \\
\hline $\mathrm{R}^{2}$ & 0.91 & 0.98 & 0.98 & 0.91 & 0.99 & 0.98 \\
\hline $\operatorname{RESET~F}(\cdot)$ & 6.04 & 1.78 & 3.08 & 5.80 & 2.36 & 3.45 \\
\hline Prob. $>$ F & 0.00 & 0.17 & 0.04 & 0.00 & 0.09 & 0.03 \\
\hline
\end{tabular}

Note: All regressions include a 2003 dummy (not reported). Robust standard errors in parentheses. RESET is Ramsey's RESET test for omitted variables, H0: no omitted variables.

All independent variables except FDI are in changes in columns (9) and (12).

$*, * *, * * *$ denote significance at the ten, five, and one percent level, respectively. 
Table 9: FDI and Skilled Wages

\begin{tabular}{|c|c|c|c|c|c|c|}
\hline Dependent Variable & $\begin{array}{c}\text { Wages } \\
(1)\end{array}$ & $\begin{array}{c}\text { Wages } \\
(2)\end{array}$ & $\begin{array}{c}\Delta \text { Wages } \\
(3)\end{array}$ & $\begin{array}{c}\text { Wages } \\
(4)\end{array}$ & $\begin{array}{c}\text { Wages } \\
(5)\end{array}$ & $\begin{array}{c}\Delta \text { Wages } \\
(6)\end{array}$ \\
\hline \multirow[t]{2}{*}{ Unweighted FDI } & 0.011 & -0.016 & 0.019 & & & \\
\hline & $(0.019)$ & $(0.025)$ & $(0.045)$ & & & \\
\hline \multirow[t]{2}{*}{ Distance Weighted FDI } & & & & $0.072^{*}$ & 0.057 & 0.119 \\
\hline & & & & $(0.042)$ & $(0.069)$ & $(0.106)$ \\
\hline Fixed Effects? & No & Yes & Yes & No & Yes & Yes \\
\hline Observations & 92 & 92 & 92 & 92 & 92 & 92 \\
\hline $\mathrm{R}^{2}$ & 0.82 & 0.97 & 0.97 & 0.77 & 0.97 & 0.97 \\
\hline $\operatorname{RESET~F}(\cdot)$ & 1.30 & 4.44 & 1.18 & 3.22 & 5.77 & 0.15 \\
\hline \multirow[t]{2}{*}{ Prob. $>$ F } & 0.28 & 0.01 & 0.33 & 0.03 & 0.00 & 0.93 \\
\hline & $(7)$ & $(8)$ & (9) & $(10)$ & (11) & $(12)$ \\
\hline \multirow[t]{2}{*}{ Maquila FDI } & 0.001 & $-0.023^{* *}$ & $-0.031^{* * *}$ & & & \\
\hline & $(0.004)$ & $(0.010)$ & $(0.011)$ & & & \\
\hline \multirow[t]{2}{*}{ Non-maquila FDI } & 0.0011 & 0.013 & 0.048 & & & \\
\hline & $(0.018)$ & $(0.023)$ & $(0.042)$ & & & \\
\hline \multirow[t]{2}{*}{ U.S. FDI } & & & & -0.005 & $-0.040^{* *}$ & -0.031 \\
\hline & & & & $(0.016)$ & $(0.019)$ & $(0.032)$ \\
\hline \multirow[t]{2}{*}{ Non-U.S. FDI } & & & & 0.013 & 0.025 & 0.044 \\
\hline & & & & $(0.010)$ & $(0.026)$ & $(0.041)$ \\
\hline Fixed Effects? & No & Yes & Yes & No & Yes & Yes \\
\hline Observations & 92 & 92 & 92 & 92 & 92 & 92 \\
\hline $\mathrm{R}^{2}$ & 0.82 & 0.97 & 0.98 & 0.82 & 0.97 & 0.97 \\
\hline RESET F $(\cdot)$ & 1.32 & 3.57 & 0.14 & 1.68 & 5.87 & 0.12 \\
\hline Prob. $>\mathrm{F}$ & 0.27 & 0.03 & 0.93 & 0.18 & 0.00 & 0.95 \\
\hline
\end{tabular}

Note: Skilled wages are measured as the log of total remuneration per non-production worker. All regressions include the same regressors as the regressions in Tables 8a and 8b as well as a 2003 dummy (not reported). Robust standard errors in parentheses.

RESET is Ramsey's RESET test for omitted variables, H0: no omitted variables. $*,{ }^{*},{ }^{* * *}$ denote significance at the ten, five, and one percent level, respectively. 
Table 10: FDI and Unskilled Wages

\begin{tabular}{|c|c|c|c|c|c|c|}
\hline Dependent Variable & $\begin{array}{c}\text { Wages } \\
(1)\end{array}$ & $\begin{array}{c}\text { Wages } \\
(2)\end{array}$ & $\begin{array}{c}\Delta \text { Wages } \\
(3)\end{array}$ & $\begin{array}{c}\text { Wages } \\
(4)\end{array}$ & $\begin{array}{c}\text { Wages } \\
(5)\end{array}$ & $\begin{array}{c}\Delta \text { Wages } \\
(6)\end{array}$ \\
\hline Unweighted FDI & $\begin{array}{c}0.010 \\
(0.007)\end{array}$ & $\begin{array}{c}0.002 \\
(0.022)\end{array}$ & $\begin{array}{c}0.015 \\
(0.038)\end{array}$ & & & \\
\hline Distance Weighted FDI & & & & $\begin{array}{c}0.023 \\
(0.034)\end{array}$ & $\begin{array}{c}0.065 \\
(0.089)\end{array}$ & $\begin{array}{c}0.134 \\
(0.122)\end{array}$ \\
\hline Fixed Effects? & No & Yes & Yes & No & Yes & Yes \\
\hline Observations & 92 & 92 & 92 & 92 & 92 & 92 \\
\hline $\mathrm{R}^{2}$ & 0.82 & 0.94 & 0.98 & 0.80 & 0.94 & 0.98 \\
\hline RESET F $(\cdot)$ & 1.29 & 1.96 & 4.20 & 1.88 & 1.39 & 5.38 \\
\hline Prob. $>$ F & 0.29 & 0.14 & 0.01 & 0.14 & 0.26 & 0.00 \\
\hline & $(7)$ & (8) & (9) & (10) & (11) & (12) \\
\hline Maquila FDI & $\begin{array}{c}0.002 \\
(0.003)\end{array}$ & $\begin{array}{c}0.001 \\
(0.011)\end{array}$ & $\begin{array}{c}0.005 \\
(0.014)\end{array}$ & & & \\
\hline Non-maquila FDI & $\begin{array}{c}0.009 \\
(0.008)\end{array}$ & $\begin{array}{c}0.010 \\
(0.025)\end{array}$ & $\begin{array}{c}0.027 \\
(0.034)\end{array}$ & & & \\
\hline U.S. FDI & & & & $\begin{array}{l}-0.002 \\
(0.010)\end{array}$ & $\begin{array}{c}-0.041^{*} \\
(0.024)\end{array}$ & $\begin{array}{l}-0.056 \\
(0.037)\end{array}$ \\
\hline Non-U.S. FDI & & & & $\begin{array}{c}0.007 \\
(0.007)\end{array}$ & $\begin{array}{c}0.023 \\
(0.029)\end{array}$ & $\begin{array}{c}0.046 \\
(0.037)\end{array}$ \\
\hline Fixed Effects? & No & Yes & Yes & No & Yes & Yes \\
\hline Observations & 92 & 92 & 92 & 92 & 92 & 92 \\
\hline $\mathrm{R}^{2}$ & 0.82 & 0.94 & 0.98 & 0.82 & 0.95 & 0.98 \\
\hline RESET F $(\cdot)$ & 1.36 & 2.14 & 4.22 & 1.42 & 1.11 & 4.89 \\
\hline Prob. $>$ F & 0.26 & 0.12 & 0.01 & 0.24 & 0.36 & 0.01 \\
\hline
\end{tabular}

Note: Unskilled wages are measured as the log of total remuneration per production worker. All regressions include the same regressors as the regressions in Tables 8a and 8b as well as a 2003 dummy (not reported). Robust standard errors in parentheses.

RESET is Ramsey's RESET test for omitted variables, H0: no omitted variables. $*, * *, * * *$ denote significance at the ten, five, and one percent level, respectively. 
Table 11: FDI and Inequality

\begin{tabular}{|c|c|c|c|c|c|c|}
\hline Dependent Variable & $\begin{array}{l}\text { Share } \\
(1)\end{array}$ & $\begin{array}{c}\text { Share } \\
(2)\end{array}$ & $\begin{array}{c}\Delta \text { Share } \\
(3)\end{array}$ & $\begin{array}{c}\text { Share } \\
(4)\end{array}$ & $\begin{array}{c}\text { Share } \\
(5)\end{array}$ & $\begin{array}{c}\Delta \text { Share } \\
(6)\end{array}$ \\
\hline Unweighted FDI & $\begin{array}{c}0.007^{* * *} \\
(0.002)\end{array}$ & $\begin{array}{l}-0.003 \\
(0.004)\end{array}$ & $\begin{array}{l}-0.002 \\
(0.011)\end{array}$ & & & \\
\hline Distance Weighted FDI & & & & $\begin{array}{c}0.004 \\
(0.008)\end{array}$ & $\begin{array}{l}-0.006 \\
(0.012)\end{array}$ & $\begin{array}{l}-0.013 \\
(0.022)\end{array}$ \\
\hline Fixed Effects? & No & Yes & Yes & No & Yes & Yes \\
\hline Observations & 92 & 92 & 92 & 92 & 92 & 92 \\
\hline $\mathrm{R}^{2}$ & 0.94 & 0.99 & 0.87 & 0.94 & 0.99 & 0.87 \\
\hline RESET F $(\cdot)$ & 4.71 & 2.48 & 1.54 & 6.83 & 2.19 & 1.50 \\
\hline Prob. $>$ F & 0.00 & 0.08 & 0.22 & 0.00 & 0.11 & 0.23 \\
\hline & $(7)$ & $(8)$ & $(9)$ & $(10)$ & $(11)$ & $(12)$ \\
\hline Maquila FDI & $\begin{array}{c}0.001 \\
(0.001)\end{array}$ & $\begin{array}{c}-0.004^{* *} \\
(0.002)\end{array}$ & $\begin{array}{c}-0.007^{* *} \\
(0.003)\end{array}$ & & & \\
\hline Non-maquila FDI & $\begin{array}{c}0.005^{* *} \\
(0.002)\end{array}$ & $\begin{array}{l}-0.001 \\
(0.005)\end{array}$ & $\begin{array}{l}-0.001 \\
(0.010)\end{array}$ & & & \\
\hline U.S. FDI & & & & $\begin{array}{c}0.002 \\
(0.003)\end{array}$ & $\begin{array}{c}0.002 \\
(0.004)\end{array}$ & $\begin{array}{c}0.005 \\
(0.008)\end{array}$ \\
\hline Non-U.S. FDI & & & & $\begin{array}{l}0.003^{*} \\
(0.002)\end{array}$ & $\begin{array}{l}-0.001 \\
(0.005)\end{array}$ & $\begin{array}{l}-0.004 \\
(0.009)\end{array}$ \\
\hline Fixed Effects? & No & Yes & Yes & No & Yes & Yes \\
\hline Observations & 92 & 92 & 92 & 92 & 92 & 92 \\
\hline $\mathrm{R}^{2}$ & 0.94 & 0.99 & 0.88 & 0.94 & 0.99 & 0.87 \\
\hline RESET F $(\cdot)$ & 5.48 & 3.60 & 2.67 & 5.50 & 2.52 & 1.38 \\
\hline Prob. $>$ F & 0.00 & 0.02 & 0.06 & 0.00 & 0.08 & 0.27 \\
\hline
\end{tabular}

Note: Inequality is measured as the share of remuneration for non-production workers in total remuneration.

All regressions include the same regressors as the regressions in Tables $8 \mathrm{a}$ and $8 \mathrm{~b}$ as well as a 2003 dummy (not reported). Robust standard errors in parentheses

RESET is Ramsey's RESET test for omitted variables, H0: no omitted variables.

$*, * *, * * *$ denote significance at the ten, five, and one percent level, respectively. 
Figure 1: FDI Flows 1994-2005, by Major Sector, Millions of U.S. Dollars

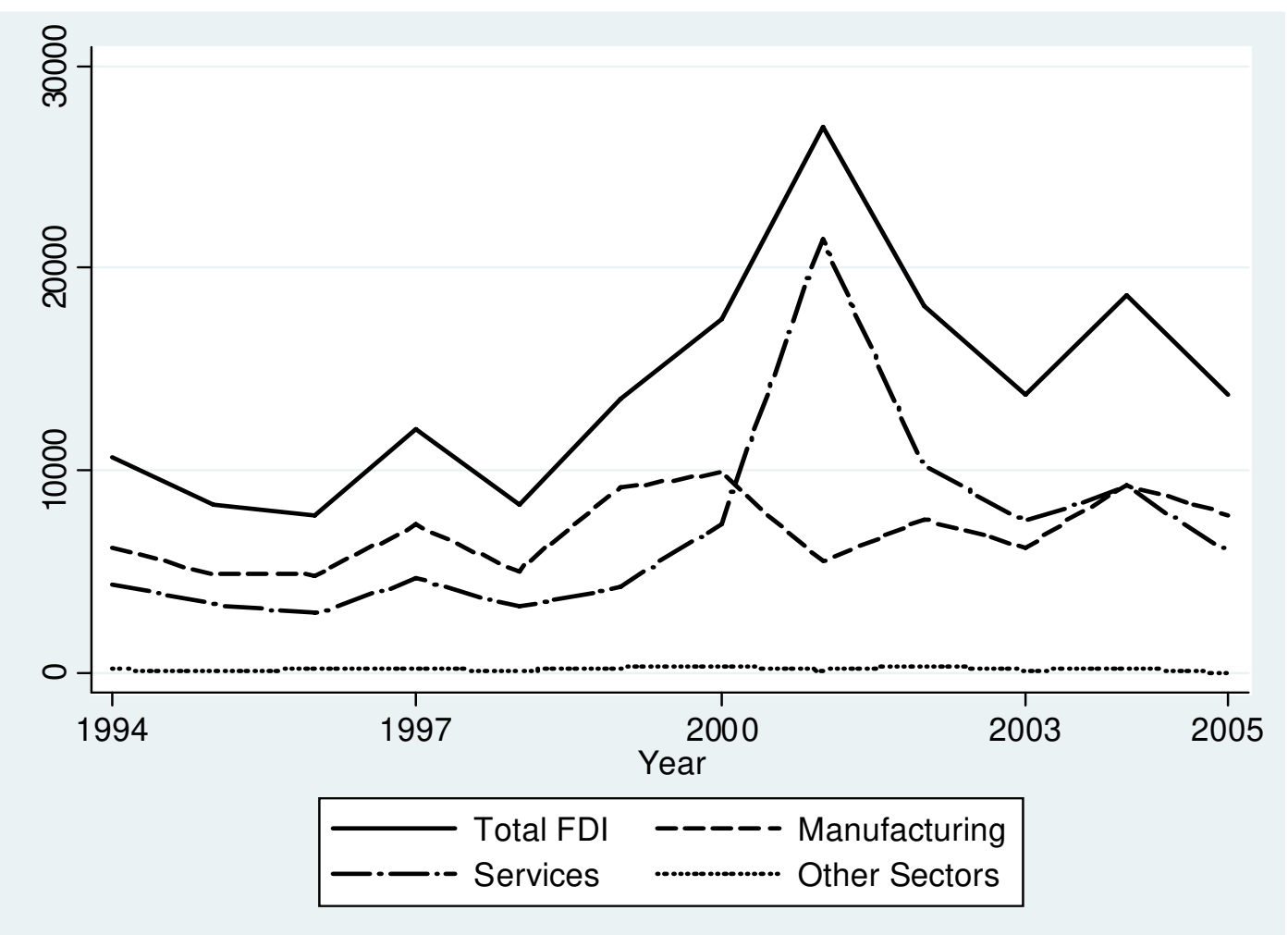

\section{Data Appendix}

Sources:

All FDI data is from Secretaría de Economía, Mexico. The distance data used to compute distanceweighted FDI is from Centre d'Etudes Prospectives et d'Informations Internationales (CEPII). Value added, capital, labor (skilled and unskilled), remuneration (skilled and unskilled), industry output and number of firms are from the 1994, 1999, and 2004 Industrial Census, conducted by Instituto Nacional de Estadística Geografía e Informática (INEGI). 2-digit industry level Producer Price Index data is also from INEGI; the U.S. Producer Price Index is from the Bureau of Labor Statistics. Exchange rate data is from International Financial Statistics (IFS). Export and import data are from the Center for International Data at the University of California-Davis.

Variables:

Unless noted otherwise, variables are in natural logarithms.

Total Factor Productivity: computed as described in the text using value added, net fixed assets, total workforce and material inputs. Nominal values in Mexican pesos were deflated using a 2-digit level producer price index and converted to U.S. dollars using the annual average market exchange rate. Industry classification is at the 4-digit level according to the Mexican Industrial Classification system (known by its Spanish acronym CMAP).

Labor Productivity: real value added, converted to '000s of U.S. dollars, divided by total workforce. 
Wages: total annual real remuneration per worker. Skilled wages are those for empleados (nonproduction workers), unskilled wages are those for obreros (production workers). Inequality is the share of remuneration of non-production workers in total remuneration.

FDI: since all published FDI data is reported in U.S. dollars, the U.S. producer price index is used to convert them to real values, in '000s of dollars.

Distance Weighted FDI: computed using the formula (13) given in the text. Distance is in kilometers, computed by CEPII using domestic and international distances weighted by the population concentration in important cities within a country.

Quality of Labor: proxied by the share of remuneration for non-production workers in total remuneration, as described above.

Scale: proxied by the average plant size in an industry, which is total industry real output, deflated using the 2-digit industry-level producer price index and converted to '000s of U.S. dollars, divided by the number of plants in the industry.

Concentration: proxied by the number of plants in an industry.

Capital(-Labor Ratio): Capital is real net fixed assets. The capital-labor ratio is capital divided by the total workforce. 